\title{
Polisemie in die woordeboek — 'n kognitiewe perspektief
}

\author{
P.H. Swanepoel, Departement Afrikaans, Universiteit van Suid-Afrika
}

\begin{abstract}
Polysemy in the Dictionary - a Cognitive Perspective. The main purpose of this article is to explicate Geeraerts's claim (cf. Geeraerts 1983b, 1990a) that prototype semantics is well suited as a basis for lexicographical metatheory. With Geeraerts's view of prototype semantics and the metalexicographical principles expounded in Zgusta (1971) as a framework, a systematic analysis is given of various aspects of polysemy in the dictionary, e.g. the basic approach to lexical categories as classical categories, views on the prototype structure of polysemous items, the problem of monosemic prototype categories vs. polysemous prototype categories, the need for schemas, and the ways in which the multi-dimensional semantic structure of lexical categories are mapped onto dictionary entries. It is shown that Zgusta (1971) constantly relativizes his proposed lexicographical metatheory as a result of some of the basic attributes of polysemous categories, viz. their vague internal and external boundaries and their complex internal semantic structure.
\end{abstract}

\section{Keywords: LEXICOGRAPHICAL METATHEORY, POLYSEMY, LEXICAL CATEGORIES,} PROTOTYPE SEMANTICS, PROTOTYPE CATEGORIES

Opsomming: Die hoofdoel van hierdie artikel is om 'n uiteensetting te gee van Geeraerts (1983b, 1990a) se aanspraak dat prototipesemantiek ' $n$ adekwate begronding vir die leksikografiese metateorie is. Uitgaande van Geeraerts se uiteensetting van prototipesemantiek en die metaleksikografiese beginsels wat in Zgusta (1971) uiteengesit word, word daar ' $n$ sistematiese ontleding gegee van verskeie aspekte van polisemie in die woordeboek, bv. die benadering van polisemiese kategorieë as klassieke kategorieë, die standpunte oor die prototipestruktuur van polisemiese kategorieë, die probleem van monosemiese prototipekategorieë teenoor polisemiese prototipekategorieë, die behoefte aan die skemabegrip en die verskillende maniere waarop die multidimensionele semantiese struktuur van leksikale items op woordeboekartikels afgebeeld word. Daar word aangetoon hoe Zgusta (1971) telkemale sy voorgestelde leksikografiese metateorie relativeer met betrekking tot van die vernaamste kenmerke van polisemiese kategorieë, nl. hulle vae interne en eksterne grense en hulle komplekse interne semantiese struktuur.

Sleutelwoorde: LEKSIKOGRAFIESE METATEORIE, POLISEMIE, LEKSIKALE KATEGORIEë, PROTOTIPESEMANTIEK, PROTOTIPEKATEGORIEë

\section{Inleiding}

Die term polisemie word op algemene wyse in die taalkunde gebruik om te verwys na die verskynsel dat twee of meer semanties verwante betekenison- 
derskeidinge met dieselfde woordvorm geassosieer word. Op die leksikale vlak kom hierdie soort betekenisvariasie voor by leksikale items (soos huis, vas en oor), subleksikale vormelemente (bv. die betekenisvariasie van -huis- as lid van komposita soos motorhuis en kleinhuisie) en by meerwoordlekseme (bv. idiomatiese uitdrukkings wat sowel ' $n$ letterlike as ' $n$ idiomatiese interpretasie kan hê).

Die beskrywing van die polisemiese struktuur van die leksikale items van ' $n$ taal is die primêre taak van die verklarende leksikografie - ' $n$ taak wat met mindere en meerdere mate van sukses in die magdom omvattende en beperkte, sinchroniese en/of historiese eentalig-verklarende woordeboeke uitgevoer word. Ten spyte van die sukses waarmee leksikograwe hierdie taak uitvoer, is die verskynsel leksikale polisemie en die linguisties-teoretiese en die metaleksikografiese begronding daarvan sekerlik een van die vernaamste probleme waarmee daar in die verskillende gebiede geworstel word.1

Die hoofdoel van hierdie artikel is om nader in te gaan op die onderstaande stellinge van Geeraerts, nl. (i) dat die prototipeteorie (afgekort: PT) van leksikale kategorieë wat binne die raamwerk van die kognitiewe semantiek (afgekort: KS) ontwikkel is (en aan die ontwikkel is), 'n empiries- en verduidelikend-adekwate teorie van leksikale polisemie daarstel, en (ii) dat hierdie teorie as teoretiese begronding vir ' $n$ metaleksikografiese teorie van leksikale polisemie kan dien.

Geeraerts meld in hierdie verband:

... it is only with the advent of prototype theory that contemporary linguistics developed a valid model for the polysemy of lexical items. This is perhaps the single most appealing characteristic of prototype theory: here at last is a descriptive approach to lexical meaning in which our pretheoretical intuitions about gradedness, fuzziness, flexibility, clustering of senses, etc. receive due attention. (Geeraerts 1989b: 591)2

En:

... prototype semantics is well suited as a theoretical basis for lexicographical metatheory, since it accurately models the kind of semantic

1 Getuie hiervan is die magdom artikels in die taalkunde en die leksikografie oor die verskillende fasette van hierdie onderwerp (vgl: Zgusta en Farina 1988 vir 'n volledige lys van die leksikografie-geörienteerde artikels).

2 Geeraerts (1989b: 590) brei soos volg op hierdie lys semantiese verskynsels uit wat in die prototipeteorie hulle regmatige deel kry:

The fuzzy boundaries of lexical categories, the existence of typicality scales for the members of a category, the flexible and dynamic nature of word meanings, the importance of metaphor and metonymy as the basis of that flexibility. 
phenomena that lexicographers have to face up to in their pragmatically restricted descriptive activities ... (Geeraerts 1990a: 210)

Geeraerts poneer in hierdie verband 'n algemene adekwaatheidskriterium vir die keuse van 'n gepaste linguistiese teorie vir die begronding van die metaleksikografie as hy beweer:

For one thing, lexicographical metatheories had better abandon all hope of building an adequate theory of lexicography on a linguistic basis that does not conform with their own experience; in particular, extant attempts to impose a structuralist conception of semantic structure on the methodology of lexicography should be rejected as misguided: there are now simply much more suitable semantic theories available. (Geeraerts 1990a: 210)

Gegee die breë empiriese begronding van die leksikografie, voorsien Geeraerts dat daar noodsaaklikerwyse 'n wedersydse wisselwerking tussen linguistiese teorievorming en die leksikografie moet bestaan, d.i. dat linguistiese teorieë nie alleen ' $n$ invloed op die leksikografiese praktyk moet uitoefen nie, maar dat die empiriese bevindinge van die leksikografie - gegee die onregstreekse relasie tussen leksikografieteorie en -praktyk - ook bepaalde eise en beperkinge aan semantiese teorievorming sal moet oplê. ${ }^{3}$

Geeraerts se opmerkings hier bo moet mens beoordeel teen die agtergrond van die volgende: (i) die gespanne verhouding wat tot nog toe tussen die leksikografie en die teoretiese linguistiek bestaan het; (ii) die huidige metaleksikografiese begronding van die leksikografie, en polisemie dan in die besonder; en (iii) die wyse waarop die KS as alternatief vir bestaande semantiese teorieë beskou kan word.

Die spanning waarvan daar in (i) sprake is, setel hoofsaaklik daarin dat daar in verskillende semantiese teorieë dikwels aan die soort verskynsels en probleme verbygegaan word waarmee die leksikograaf gekonfronteer word in

Uitgaande van die standpunt dat woordeboeke 'n beskrywing gee van die aktueringe van 'n woord betekenis en hulle strukturele verband binne die betekeniseenheid, toon Geeraerts in feite aan dat woordeboeke in die praktyk deur die aannames van die prototipeteorie gelei word en dat nie die leksikografiese praktyk nie, maar slegs die teoretiese begronding daarvan aanpassings verg (vgl. Geeraerts 1983c: 198). In Geeraerts (1983a: 2) word verklaar:

Prototype theory is corroborated by the empirical findings of lexicography, and that, in this respect, it is eminently suited as a framework for dictionary making.

Geeraerts (1990a: 210) meld ook in hierdie verband:

But the rapprochement could not be unidirectional: it would seem that prototype semantics might profit a lot from a closer acquaintance with the detailed descriptions of prototypical structures contained in large-scale traditional dictionaries as the Woordenboek der Nederlandsche Taal. 
die ontleding en beskrywing van polisemiese kategorieë in lewende taalgebruik (vgl. Geeraerts 1987a: 1-2).4 In die leksikografie is hierdie leemtes in die verlede (en word hulle sekerlik vandag nog) oorkom deur op eklektiese wyse 'n metaleksikografie te konsipieer om die taak van die ontleding en leksikografiese beskrywing van leksikale semantiese variasie aan te pak. Vir hierdie doel word daar gesteun op van die meer bruikbare en insiggewende uitgangspunte en teoretiese apparatuur van die bestaande leksikaal-semantiese teorieë, "gut feelings" en tradisionele praktyke, soos vereis en beperk deur die pragmatiesfunksionele doelstellings van die verskillende soorte woordeboeke en die inligtingsbehoeftes van die verskillende kategorieë woordeboekgebruikers.

Die implikasie van Geeraerts se stellinge hier bo is dus dat die kognitiewe prototipeteorie, vanweë die begronding daarvan in die soort empiriese verskynsels en probleme van die leksikografie, 'n beter teoretiese raamwerk vir die begronding van die metaleksikografie daarstel as ander raamwerke, in die besonder strukturalisties-georiënteerde raamwerk.

Hierdie stelling roep 'n aantal vrae op waarop daar in hierdie artikel in meer besonderhede ingegaan sal word. Die eerste hiervan sentreer om die vraag na die besondere variant van die prototipeteorie wat hier ter sake is en hoe dié in teoretiese en empiriese begronding van strukturalisties-georiënteerde semantiese teorieë verskil. Geeraerts neem as besondere vertrekpunt in sy verskillende artikels (vgl. die bronnelys vir besonderhede) vier hoofkenmerke van prototipekategorieë wat in verskillende variante of weergawes van prototipeteorieë aan die orde gestel word. Die KS vorm egter geen teoretiese of deskriptiewe homogene paradigma nie (vgl. Rudzka-Ostyn 1988; Geeraerts $1989 \mathrm{~b}$ ), nog minder is daar slegs een opvatting van die kembegrippe "prototipe" en "prototipekategorie"s soos wat dit as relevant vir die leksikografie beskou kan word. Geeraerts meld self dat die begrip "prototipeteorie" as 'n prototipie-

Geeraerts (1987a: 1-2) meld in hierdie verband:

... linguistic theories have only rarely devoted attention to lexicography, and to the linguistic facts revealed by it. As an empirical discipline that yields a large-scale overview of language, lexicography is very much aware of the difficulties and vicissindes of achual linguistic data, i.e. of all the irregularity and vagueness that is often ignored by linguists as being theoretically irrelevant, but that forms the most important part of the lexicographer's daily experience of language. The theoretical preference for regularity and simplicity has pushed the lexicographers away from linguistics by leaving them without adequate models to deal with vague and irregular facts, a development that is already implicit in Bloomfield's definition of the lexicon as the set of irregularities of the language.

Geeraerts (1989b: 606) isoleer dit as een van die hooftake van die verdere teoretiese ontwikkeling van die kognitiewe linguistiek "to sort out and compare the diverse phenomena that have been lumped together under the label of prototypicality, and the various ways in which these may be incorporated into semantic theories". 
se begrip hanteer moet word vir sover as wat "There are ... central as well as more peripheral examples of prototypical theories" (1989b: 602).6

Teen hierdie agtergrond word daar in hierdie artikel gepoog om 'n uiteensetting te gee van die "Geeraertsiaanse" weergawe van PT, wat duidelikheidshalwe binne van die sentrale aannames van KS gesitueer word om sodoende van die belangrikste verskille daarvan met strukturalistiese teorieë uit te lig. Die hoofdoel van hierdie uiteensetting is eenvoudig om die besondere variant van PT nader te belig, maar dan ook om, waar nodig, dit teen die leksiografieteorie en -praktyk te spieël en om uiteindelik die heuristiese waarde van die teorie vir die leksikografiepraktyk aan te toon.

Die tweede probleem het te make met die adekwaatheid van die bestaande metaleksikografiese begronding van polisemie. Verskeie outeurs is van mening dat die leksikografie hom as 't ware in ' $n$ teorebiese vakuum bevind. Wierzbicka (1990: 366) meld in hierdie verband:

... lexicography has always lacked a theoretical basis ... Lexicographers have grappled with their 'practical' tasks without any theoretical framework ... Given this lack of help from semantic theory, it is the lexicographers' achievements, not their failures, which are truly remarkable.

So 'n stelling moet mens egter met die nodige omsigtigheid behandel. Die feit dat daar in bestaande semantiese teorieë geabstraheer word van die soort taalgebruiksprobleme wat sentraal in die leksikografie staan, impliseer nie dat die leksikografie self geen teoretiese basis het nie. In die samestelling van enige woordeboek word die leksikograaf voor die feit gestel dat hy 'n aantal prinsipiële besluite moet neem oor hoe die verskynsel van leksikale betekenisvariasie afgebaken moet word, hoe hierdie beskouinge die ontleding van betekenisvariasie-in-konteks sal rig, en uiteindelik ook oor hoe hierdie verskynsel op die makro- en die mikrostrukturele vlak beskryf gaan word. Hiervoor formuleer hy, al sy dit net vir homself en 'n woordeboekredaksie, 'n aantal metaleksikografiese riglyne, waarvan sommige direk linguisties van aard is en ander op die vlak van pragmaties-funksionele oorweginge lê.

Problematiese aspekte van die uitgangspunte en begrippe van die prototipeteorie kom aan bod in verskeie artikels in Tsohatzidis (1990). Van hierdie kritiek raak aan wesentlike aspekte van die prototipeteorie as begronding vir 'n leksikaal semantiese teorie. Van die punte wat geopper word, is bv. die geldigheid van die psigoleksikale metodologie wat gevolg word en die interpretasie van die gelewerde resultate; die relevansie van die psigoleksiale bevindinge vir ' $n$ teorie van leksikale semantiek; die wyse waarop die begrip "prototipe" ingespan word om die gebrek aan die voorspellende krag van geponeerde definisies te ondervang; die deureenhaspeling van leksikale kategorieë sonder inagneming van hulle wesentlike konseptuele verskille; die vae kriteria waarvolgens gevalle van monosemie van polisemie onderskei kan word. 
Wat die linguisties-teoretiese begronding van polisemie betref, sou mens, maar dan ook gedagtig aan die gevaar van oorvereenvoudiging, kon sê dat daar in die leksikografie op 'n minimale teoreties-analitiese raamwerk gesteun word, waarvan die kernkonsepte aan die histories-filologiese semantiek (vgl. byvoorbeeld konsepte soos "figuurlike" vs. "letterlike" betekenisonderskeidinge; "primêre" vs. "sekondêre" betekenisonderskeidinge; "betekenisverruiming" (-generalisasie), "betekenisverenging" (-spesialisering) en 'betekenisverskuiwing") en die strukturele semantiek (vgl. byvoorbeeld konsepte soos "betekeniskenmerke", "semantiese velde", "komponensiële analise", ens.) ontleen is. Vgl. in hierdie verband bv. Ayto (1983), Landau (1984) en Zgusta (1971).

Hierdie feit neem egter nie weg dat daar tot op hede geen algemeen aanvaarde en homogene leksikografiese teorie van polisemie is nie, of dat bestaande metaleksikografiese uitgangspunte as "adekwaat" beskou hoef te word nie. Die vraag wat dus by mens opkom, is of PT inderdaad teoreties en deskriptief 'n beter raamwerk daarstel as bestaande metaleksikografiese raamwerke. Lehrer (1990: 370), wat in hierdie verband bv. besonder skepties is ten opsigte van die aanname in PT van die vaagheid van kategorieë, sê die volgende:

Working lexicologists and lexicographers have long been aware of fuzziness and have tried to cope with it. Therefore, it seems that the effect of PT on the average working semanticist may not be so great after all. The semanticist still constructs definitions, and the features of definitions may be arranged in order of importance. What differs is that the status of the features may change from necessary to probable or possible.

Geeraerts (1989c: 292) maak bv. ook die besondere sterk aanspraak dat die insig dat polisemiese leksikale items tipies die vorm aanneem van betekenisklosters rondom sentrale betekenisonderskeidinge as 't ware een van die groot ontdekkinge van KS is,? terwyl dit by ' $n$ herlees van ' $n$ werk soos Zgusta (1971) maar te duidelik blyk dat daar in sy besondere, maar strukturalisties-georiënteerde metaleksikografie allerlei teoreties-konseptuele aanpassinge gemaak word om juis hierdie bekende feit te akkommodeer.

Soos Geeraerts egter al verskeie kere self opgemerk het, is dit problematies om afleidinge van 'n teoretiese aard uit die leksikografiese praktyk te maak omdat

7

Geeraerts (1989c: 292) meld:

Specifically, recent developments in lexical semantics have convincingly shown that the canonical form of polysemous categories is one in which semantically distinct applications of a word are clustered round one or more central meanings... This prototypical conception of lexical semantic structures accords very well with the conclusions that may be drawn from lexicographical practice ..." 
(i)

(ii)

nie alle teoretiese uitgangspunte wat in die leksikografie verdedig word noodsaaklik ook in die praktyk neerslag vind nie (en omgekeerd);

bestaande teorieë dit wat al lankal in die leksikografiepraktyk bestaan, dikwels net versterk, sanksioneer of linguisties-teoreties plaas, sodat dit moeilik is om uit die woordeboekpraktyk te bepaal presies wat teoreties as "nuut" of eie aan die leksikografieteorie beskou kan word; 8

die woordeboekpraktyk, naas teoretiese, ook deur pragmaties-funksionele oorweginge gestuur word, wat in hierdie geval aan die beskrywing en weergawe van polisemiese betekenisvariasie allerlei beperkinge op die implementeerbaarheid van teoretiese oorwegings lê, selfs al sou sulke oorweginge 'n rigtinggewende rol in die ontleding van betekenisvariasie kon speel (vgl. Geeraerts 1983a: 1, 1990a: 197 e.v.).9

Teen hierdie agtergrond word daar in hierdie artikel ook in meer besonderhede ingegaan op die wyse waarop die uitgangspunte en konsepte van die prototipeteorie by ' $n$ besondere metaleksikografie, nl. dié van Zgusta (1971), aansluit respektiewelik daarvan verskil, en hoe hierdie uitgangspunte en insigte in

Geeraerts (1989b: 608, voetnoot 9) wys self daarop dat

... as a theory about the (radial, clustered, dynamically flexible) structure of polysemy, prototype theory is to a considerable extent a rediscovery of views that were paramount during the prestructuralist era of the development of lexical semantics, and that lingered on below the surface in the structuralist and transformationalist periods.

As teorie inkorporeer KS uitgangspunte van verskeie ander tradisies van semantieknavorsing (vgl. Geeraerts 1989b: 607 en 1988b).

Op grond hiervan kom Geeraerts (1987a: 2) dan tot die slotsom dat 'n adekwate leksikografieteorie enersyds 'n skakel met die teoretiese linguistiek moet lê, en andersyds dat dit ' $n$ teoretiese basis vir die begronding van die pragmatiese funksie van woordeboeke moet bied. Een van die wyses waarop so 'n teorie hieraan kan voldoen, skets Geeraerts (1987: 2) soos volg:

This can be done by showing how the actual diversity of dictionaries consists of a choice from among theoretically defined alternative objects or points of view of linguistic description, and how particular choices are determined by functional considerations. Hence, there will be three main parts to a theory of lexicography: first, an overview of the lexicographically available choices with regard to the information to be included in the dictionary and with regard to the way of representing it; second, a theoretical part showing how those alternatives can be connected with linguistically definable aspects of language; and third a functional part showing how the choice among those alternatives is determined by pragmatic considerations, i.e. by the pragmatic function of the lexicographical work. In a sense, theoretical lexicography has to show how actual dictionaries are sihuated at the intersection of theoretical and pragmatic considerations. 
die leksikografiepraktyk neerslag vind. Een van die verrassende aspekte by die herlees van Zgusta (1971) is juis hoe hy vanweë die problematiese aspekte van die empiriese gegewe allerlei metaleksikografiese aanpassinge maak aanpassinge wat ten nouste aansluit by teoretiese en metodologiese uitgangspunte van kognitiewe prototipeteorieë. En ook vanuit hierdie perspektief sal daar in hierdie artikel aangetoon word dat die teorie allerlei alternatiewe bied van waaruit ou leksikografiese probleme opnuut bekyk kan word.

Vanweë die beperkte omvang van hierdie artikel word daar net in meer besonderhede ingegaan op die breë kategorie-opvattinge in die raamwerk van die kognitiewe semantiek. Kategorie-interne relasies, soos metonimie, metaforiek en beeldskematiese uitbreidings word dus vir eers buite beskouing gelaat.

\section{Die struktuur van leksikale kategorië}

\subsection{Konsepte en kategorieë}

Een van die sentrale aannames in KS oor leksikale betekenis is dat die konsepte wat met leksikale items geassosieer word as kategorieë gekonseptualiseer kan word. Oor die psigoleksikale begronding hiervan meld Brown (1990: 17):

People create categories by assigning the same name or label to different things. When speakers of a language are in general agreement with respect to the different entities to which a single term applies, the pertinent category is a component of natural language.

As sodanig funksioneer konseptuele kategorieë wesentlik as patroonherkennende meganismes met behulp waarvan entiteite in die werklikheid geklassifiseer word in groepe wat as verwant of gelyk beskou word. Hierdie kategoriserende funksie behels dat daar bepaal word of ' $n$ spesifieke entiteit lid is van ' $n$ konsep/kategorie of lid van 'n subversameling van 'n ander konsep/kategorie.

Die terme konsep en kategorie word in hierdie verband soms as sinonieme gebruik. Ander algemene gebruike is die term konseptuele kategorie (ter onderskeiding van die opvatting dat kategorieë buite menslike kognisie sou bestaan) en die term leksikale kategorieë (ter onderskeiding van ander kategorietipes soos sinskategorieë).

In die breë kan dit gestel word dat daar in KS ondersoek gedoen word na

die beginsels wat kategorisering bepaal, d.i. die beginsels wat die groepering van entiteite in klasse met soortgelyke lede bepaal; en die struktuur van konsepte/kategorieë, om sodoende te bepaal hoe konsepte/kategorieë in menslike kognisie geberg en gerepresenteer word en watter kognitiewe funksies hulle verrig. 
Op die leksikaal-semantiese vlak is die hoofdoel van KS om te bepaal watter kategoriemodelle leksikale kategorieë onderlê, d.i. hoe monosemiese en polisemiese leksikale kategorieë intern gestruktuur is en op watter gronde die verwantskap van die betekenisonderskeidinge, -toepassinge en -nuanses van polisemiese kategorieë berus.

In die ondersoek na die kategoriestruktuur van leksikale items word daar in KS verskillende kategorietipes of -modelle onderskei wat almal vir die leksikografie van belang is, nl. die sg. "klassieke" of Aristoteliaanse kategoriemodel, die prototipekategoriemodel en kategorisering op grond van skematisering.

\subsection{Klassieke kategorië̈}

Die grootste deel van die navorsing binne KS oor die struktuur en status van 'n leksikale kategorie is ingegee deur die dominansie van die klassieke kategoriebeskouing op gebiede soos die taalkunde, kognitiewe sielkunde en kunsmatige intelligensiestudies. In KS word die bestaan van leksikale kategorieë/items met 'n klassieke kategoriestruktuur nie ontken nie - die navorsing oor prototipekategorieë demonstreer in feite

(i) die onhoudbaarheid daarvan om alle leksikale kategorieë as klassieke kategorieë te beskou, ${ }^{10} \mathrm{en}$

(ii) die onhoudbaarheid van sommige van die uitgangspunte van die komponensiële betekenisanalise waarmee die klassieke kategoriebeskouing geassosieer word.

\subsubsection{Hoofkenmerke}

Langacker (1988c: 133) som die klassieke kategoriebeskouing soos volg op:

... a category is defined by a fixed set of properties or features. These attributes are necessary and sufficient conditions for category membership, affording absolute predictability in this regard; if an entity possesses all the criterial properties, it is a member of the class; otherwise it is not. Class-membership is consequently an all-or-

Lakoff (1987: 95-96) noem die volgende as een van die kenmerke van menslike kategorisering:

No Common Properties: Categories on the whole need not be defined by common properties. On the other hand, common properties seem to play a role in characterizing the basic schemas within a given category (edible plant, human male, human female).

Lakoff maak dus voorsiening daarvoor dat die sentrale lid/lede van 'n kategorie in terme van 'n versameling noodsaaklike en afdoende kenmerke gedefinieer sou kon word. Vgl. in hierdie verband egter die bespreking in Geeraerts (1987b) oor die kategoriekonsepsie wat hierdie siening onderlê. 
nothing affair; there are no degrees of membership, nor does a category display any significant internal structure.

Geeraerts (1989b: 587) haal Rosch en Mervis (1975) in hierdie verband aan waarin hulle die volgende kenmerke aan klassieke kategorieë toeskryf:

... most traditions of thought have treated category membership as a digital, all-or-none phenomenon ... that categories are logical bounded entities, membership in which is defined by an item's possession of a simple set of criterial features, in which all instances possessing the criterial attributes have a full and equal degree of membership.

Aan die beskouing van die interne struktuur van 'n klassieke kategorie lê dus die volgende aannames ten grondslag:

dat leksikale kategorieë rigiede grense het of logies gebonde entiteite is, d.i. nie vae grense het nie, en gevolglik dat klaslidmaatskap rigied op ' $n$ binne-buite-basis beslis word;

(a) dat die kriterium vir klaslidmaatskap in terme van ' $n$ versameling (vaste) noodsaaklike en afdoende definiërende kenmerke omskryf kan word; (b) dat alle lede in 'n kategorie hierdie kenmerke deel; en ten slotte (c) dat die aanwesigheid van hierdie versameling kenmerke dit moontlik maak om klaslidmaatskap op 'n absolute wyse te voorspel;

dat leksikale kategorieë intern nie gestruktureerd is nie (aangesien gelyke status vir lede wat dieselfde kenmerke deel, geponeer word).

Aan die basis van hierdie kategoriebeskouing lê die onderskeid wat in die klassieke kategoriebeskouing tussen essensiële, definiërende ("criterial") of linguistiese kenmerke en toevallige, nie-definiërende kenmerke getref word. Ter illustrasie: die essensie van menswees kan saamgevat word in die kenmerke "twee-voetige dier". Ander kenmerke, soos haarkleur, tipiese kleredrag, ens. is toevallige kenmerke en speel nie ' $n$ sentrale rol in ons konseptualisering van menswees of in die bepaling daarvan of ' $n$ bepaalde entiteit inderdaad ' $n$ mens is of nie. (Vgl. Taylor 1989: 22.) Verder word daar aanvaar dat 'n konsep soos MENS, wat met die leksikale vorm mens geassosieer word, gedefinieer kan word deur 'n uiteensetting van die essensiële, definiërende kenmerke daarvan. Die definiërende status van hierdie kenmerke setel dan juis daarin dat hulle attribute noem "that are each indispensible for the definition in question, and that taken together suffice to delimit that concept from all others" (Geeraerts $1989 \mathrm{~b}: 588$ ). Die definiërende aard van hierdie kenmerke bestaan wesentlik uit twee komponente, nl. hulle noodsaaklikheid ("necessity") en hulle afdoendheid ("sufficiency"): 
On the one hand, a definition of a category specifies a sufficient set of conditions for any one thing to belong to that category, if the joint presence of the listed conditions guarantees that the item in question is a member of the extension of the category. On the other hand, each of the conditions mentioned in the definition is necessary to the extent that its absence guarantees that any one thing is not a member of the extension of the category. (Geeraerts 1987b: 275)

Afdoendheid is ' $n$ kenmerk van die versameling kenmerke as ' $n$ geheel, terwyl noodsaaklikheid van elkeen van die onderskeie kenmerke of voorwaardes geld. Gevolglik kan mens die uitgangspunt dat kategorieë aan die "necessitycum-sufficiency"-vereiste moet voldoen, soos volg stel: kategorieë kan/moet gedefinieer word in terme van ' $n$ afdoende versameling noodsaaklike kenmerke/voorwaardes vir kategorielidmaatskap.

Indien enige entiteit nie aan enigeen van die definiërende kenmerke van 'n kategorie $Y$ voldoen nie, dan is so ' $n$ entiteit nie ' $n$ lid van die kategorie $Y$ nie. Die definiërende kenmerke is saam afdoende om 'n kategorie te definieer sodat elke lid/entiteit wat aan elkeen van die essensiële kenmerke voldoen ipso facto lid van die kategorie is.

Die tweede aanname ten opsigte van kenmerke is dat hulle binêr van aard is. Hierdie aanname steun op die uitgangspunt dat ' $n$ entiteit nie sowel 'n kenmerk kan besit as dit nie kan besit nie. ' $n$ Entiteit besit 'n kenmerk of nie en dit behoort gevolglik tot 'n kategorie of nie. Alle kenmerke definieer dus ook 'n kategorie of hulle definieer nie ' $n$ kategorie nie, d.i. ' $n$ kenmerk is óf aanwesig óf afwesig in 'n kategorie en hulle kan ten opsigte van 'n kategorie net een van twee waardes aanneem, nl. [+] of [-].

Uit die voorafgaande volg dan die twee verdere aannames, nl. dat kategorieë duidelike grense het en dat alle lede van 'n kategorie gelyke status het.

As 'n kategorie eers tot stand gekom het, dan verdeel dit enige versameling entiteite in dié wat tot die kategorie behoort (op grond van die definiërende kenmerke daarvan) en dié wat nie daartoe behoort nie. Geen tussengevalle word erken nie, d.i. 'n entiteit kan nie in bepaalde opsigte of in 'n sekere mate lid van 'n kategorie wees nie. Gegee dat daar geen grade van kategorieskap bestaan nie, volg dit dat alle lede gelyke status ten opsigte van hulle lidmaatskap van 'n kategorie het, d.i. geen entiteite kan beter lede of voorbeelde van die kategorie as ander wees nie."11

11 Taylor (1989: 54-55) wys daarop dat die klassieke kategoriebeskouing net twee grade van kategorieskap onderskei, nl. lid of nie-lid. In die geval van prototipekategorieë is lidmaatskap ' $n$ kwessie van graad. Pogings is al aangewend om variërende grade van lidmaatskap met die klassieke kategoriebeskouing te versoen deur te aanvaar dat ten minste sommige kenmerke gradeerbaar is, d.i. dat hulle een van 'n reeks waardes tussen 0 en 1 kan aanneem. 'n Kandidaat vir hierdie soort kenmerk is die gradeerbare adjektiewe, soos 
Uit bostaande kenmerke volg dit dat 'n kategorie volgens die klassieke kategoriebeskouing as 'n polisemiese kategorie beskou moet word indien (i) dit betekenisvariasie vertoon, en (ii) dit nie moontlik is om die relevante, verwante betekenisonderskeidinge in terme van ' $n$ versameling oorkoepelende kenmerke te definieer wat die noodsaaklike en afdoende voorwaardes beskryf vir die gepaste gebruik van die leksikale item nie, of wat as basis kan dien vir die insluiting respektiewelik uitsluiting van individuele betekeniswaardes as synde deel van die betrokke leksikale item al dan nie.

Die teorie van konsepvorming wat hierdie uitgangspunt onderlê, is dat konsepvorming 'n proses van veralgemening (abstrahering) is waarvolgens individuele verskille tussen lede geneutraliseer word deur hulle gemeenskaplike identiteit, soos bepaal deur die gesigspunt van waaruit die klassifikasie plaasvind. Leksikale betekenisse sal hiervolgens altyd maksimaal algemene subversamelings van die ekstensie van 'n kategorie verteenwoordig waarvoor 'n gemeenskaplike kern gedefinieer kan word.

In die klassieke kategoriebeskouing word ooreenkoms gemeet in terme van die aantal kenmerke wat entiteite deel. En vir sover kenmerke universele, objektiewe status het, word oordele oor ooreenkoms nie met subjektiwiteit besmet nie. Ooreenkoms word gereduseer tot objektief verifieerbare gedeeltelike of volle identiteit.

\subsubsection{Problematiese aspekte}

Al aanvaar mens die bestaan van klassieke leksikale kategorieë, waarvan wetenskaplike terme en leksikale items wat natuurlike soorte definieer dikwels as voorbeelde genoem word, is die klassieke kategoriebeskouing nie sonder probleme nie. Die meeste hiervan het te make met die status en aard van die betekeniskenmerke wat as definiërende kenmerke voorgehou word.

Die eerste van hierdie probleme is die aanname dat definiërende kenmerke gelykgestel word aan die versameling linguistiese kenmerke en die niedefiniërende of toevallige kenmerke aan nie-linguistiese of ensiklopediese kenmerke.

[LANK].'n Woord sal dan sekere grade van vaagheid vertoon in dié mate waarin van hierdie gradeerbare kenmerke die betekenis daarvan definieer.

Kognitiewe semantici verwerp egter hierdie benadering omdat die soort vaagheid wat met die kategorie [LANK] geassosieer word net oppervlakkig vergelykbaar is met die prototipeeffekte van prototipekategorieë. Die vaagheid van sommige kategorieë, soos SPEL, BEKER en MEUBELSTUK, kan nie aan die vaagheid van enige van hulle definiërende kenmerke toegeskryf word nie. Daarby is die vaagheid van ' $n$ kategorie soos LANK die resultaat van 'n komplekse aantal faktore en nie net van die afgemete hoogte van iets nie. Die wyse waarop 'n entiteit gekonseptualiseer word, en die konteks waarin dit waargeneem word, speel 'n ewe belangrike rol. 
Die kriterium dat linguisties definiërende kenmerke betekenisonderskeidend werk, faal sodra enige sogenaamde nie-linguistiese kenmerk die basis vir betekenisuitbreiding binne 'n kategorie vorm of betekenisonderskeidend tussen kategorieë sou funksioneer. Geeraerts (1989b: 589) illustreer eersgenoemde geval aan die hand van die volgende voorbeeld:

Take the case of metaphorization: before lion acquires the meaning 'brave man', the feature 'brave' is not structurally distinctive within the semasiological structure of lion, and hence, it has to be considered encyclopedic according to structuralist theories. But if it can be accepted ... that the metaphorical extension of lion toward the concept 'brave man' is not just a question of diachronic change, but is merely an effect of the SYNCHRONIC flexibility of lexical items, the feature clearly acquires semantic status. If ... such synchronic metaphorical extensions may be based on any allegedly encyclopedic attribute, the distinction between semantic and encyclopedic concepts as a whole falls.

Die onderskeid tussen linguistiese (d.i. sg. definiërende/essensiële kenmerke) en ensiklopediese (of: nie-definiërende) kenmerke is sinchronies gesien dus eenvoudig irrelevant aangesien polisemiese betekenisuitbreiding óf op ensiklopediese óf linguistiese kenmerke gebaseer kan wees. Die hoofpunt hier is dat die verwantskap op grond waarvan nuwe betekeniswaardes tot ' $n$ polisemiese kategorie gereken kan word op sowel sg. ensiklopediese as linguistiese kenmerke gebaseer kan wees, in welke geval enigeen van die twee as definiërende kenmerke van die kategorie beskou kan word (vgl. Geeraerts 1989b: 594).

Verwerp mens die onderskeid tussen linguistiese en nie-linguistiese kenmerke, dan verval die onderskeid tussen analitiese en sintetiese sinne ook daarmee. Soos Haiman (1980) en Taylor (1989) aantoon, is die probleem waar, en op grond van watter kriteria mens die lyn kan trek tussen dit wat 'n spreker weet op grond van sy kennis van ' $n$ taal en dit wat hy weet op grond van sy vertroudheid met die wêreld. Taylor (1989: 81-83) wys bv. daarop dat $\sin$ (i) as analities waar aanvaar word:

(i) Honde is diere

d.i. as waar op grond van ons suiwer linguistiese kennis van die betekenisse van die woorde hond en dier. Die vraag is egter wat die status van 'n sin soos (ii) is waarin 'n reeks attribute genoem word wat almal as "waar" van die kategorie HOND sou kon geld:

(ii) Honde het vier bene/'n stert/ kan blaf/ miaau nie/ het nie horings nie 
Die vraag is of hierdie sin waar is op grond van die linguistiese betekenis van die leksikale item hond of op grond van dit wat ons van honde (in die algemeen) weet. Aanvaar ons dat hierdie sin analities is, dan impliseer dit dat ons die kenmerke [BESIT VIER BENE], [KAN BLAF] en [-BESIT VAN HORINGS] tot die lys van noodsaaklike en afdoende definiërende kenmerke van hond moet toevoeg. Dit sou egter die weg open vir 'n onbepaald lange definisie van die kategorie, aangesien die kenmerke in (ii) met ' $n$ onbeperkte aantal kenmerke aangevul kan word. Die vraag is verder of die kenmerk [DIER] in die analitiese sin (i) wesentlik verskil van die kenmerke wat in sin (ii) uitgelig word. Die punt is dat ons aanvaarding van die feit dat ' $n$ sin soos (i) noodwendig waar is, self die gevolg is van diepgesetelde opvattinge oor die innerlike samestelling van die natuurlike soorte hond en dier en van die wyse waarop hierdie soorte in ' $n$ taksonomiese hiërargie tot mekaar staan. (i) kan dus nie analities wees in die sin dat die waarheid daarvan los staan van ons eie begrip van die verhouding waarin sake in die werklikheid tot mekaar staan nie. Kortom: ons kennis van HOND word op wesentlike wyse bepaal deur 'n hele omvattende kognitiewe kompleks of domein waarbinne daar nie streng tussen linguistiese en nie-linguistiese kenmerke onderskei kan word nie.12

Hierdie feite dwing mens tot ' $n$ woordbetekenis wat breedweg ensiklopedies en konseptueel 13 van aard is. Al die bogenoemde kenniselemente vorm 'n matriks vir ons mentale representasie van die konsep HOND en dit verskaf die rasionaal vir die afbakening en kategorisering van die soort skepsels waarna as honde verwys kan word.

Die ervaring en kulturele agtergrond van taalgebruikers maak ' $n$ wesentlike deel van hierdie konseptuele kennis uit. Die betekenis van 'n groot aantal woorde kan bv. net beskryf word in terme van en teen die agtergrond van spesifieke kulturele norme of gebruike: verskeie van die attribute van koppie het bv. te make met kulturele norme vir die drink van warm vloeistowwe. As taal een van die basiese kognitiewe instrumente van die mens is, dan kan dit nie los van hierdie kognitiewe funksie, d.i. die interpretasie, ordening, berging en uitdrukking van menslike ervaring - individueel en kultureel-kollektief bestudeer word nie.

Die tweede probleem is die kriterium vir verwantskap (en dus vir kategorielidmaatskap) omdat dit nie duidelik is of alle definiërende kenmerke in die bepaling van identiteit ter sake is en of net sekere kenmerke vir hierdie doel ge-

Taylor (1989: 82) meld ten opsigte van hierdie voorbeelde dat

Our concept "dog" is not independent of our knowledge about dogs - about the status of dogs as a species within the animal kingdom, about different breeds of dog, about their appearance and behaviour, their relationship with humans, and so on.

'n Leksikale item/eenheid word in KS gesien as 'n gekonvensionaliseerde simboliese eenheid met 'n semantiese en ' $n$ fonologiese pool. Gekonvensionaliseerde leksikale betekenis is dus gelyk aan die (gekonvensionaliseerde) konsephuele representasie wat met leksikale vorme geassosieer word. 
selekteer moet word nie (vgl. Lyons 1977:553). Sou mens bv. die kenmerk [VIERPOTIG] as 'n definiërende kenmerk van HOND beskou, lewer dit 'n probleem op vir die kategorisering/benoeming van ' $n$ hond waarvan een been afgesit is. So ' $n$ hond hou nie op om ' $n$ hond te wees nie, sodat die definiërende status van hierdie kenmerk onmiddellik in die gedrang is. Verder raak dit die status van al die ander sg. definiërende kenmerke, omdat daar altyd een of ander eksemplaar van die kategorie sou kon voorkom waarby een of meer van hierdie kenmerke ontbreek of waarin dit van die betrokke kenmerk in 'n bepaalde opsig afwyk, sonder dat die betrokke eksemplaar noodwendig as lid van die betrokke kategorie uitgesluit sal word (vgl. ook Taylor 1989: 81-83).

Taylor (1989: 64) illustreer hierdie feit verder met die definiëring van die konsep DRIEHOEK, wat as 'n tipiese klassieke kategorie beskou word: driehoek word tipies soos volg gedefinieer:

... a triangle is a figure enclosed by three straight lines.

Maar:

... While the number of sides to the figure might well be a matter of either-or, the straightness of these sides is a matter of similarity to a prototype. Suppose I draw a triangle, freehand. The sides will almost certainly not be straight; they might not even join up. The figure would not be a very good example of a triangle. Yet it could still be called a triangle, and could serve as an adequate illustration of the meaning of the word triangle in a foreign language classroom.

Die derde problematiese aanname is dié dat definiërende kenmerke 'n kategorie rigied afbaken. Definieer mens HOND, soos in NWB, in terme van die kenmerke "sag- tot grofharige, vleisetende soogdier en landroofdier, veral as huisdier aangehou", dan baken dié kenmerke afsonderlik en gesamentlik nie die konsep HOND van ander kategorieë af nie. Die meeste katte vertoon bv. alle of die meeste van die betrokke kenmerke sodat die versameling kenmerke as sodanig nie spesifiek genoeg is om die betrokke leksikale item uniek van kat te onderskei nie.

Dit is een van die mites van die klassieke teorie dat alle konsepte gereduseer kan word tot versamelings binêre primitiewe. Die onhoudbaarheid van hierdie siening blyk duidelik as mens probeer om 'n eenvoudige, maar komplekse attribuut soos [VERMOë OM TE VLIEG] probeer ontleed in terme van die konstituerende attribute daarvan. Soos Taylor (1989: 62) aantoon, verdwyn die grense tussen die vermoë om te vlieg en om nie te vlieg nie sodra mens dit op vlieënde entiteite van toepassing probeer maak:

Suppose we define [ability to fly] as the ability for fairly rapid selfpropelled motion through the air. Let us take each of these sub- 
attributes in turn. How much external assistance does an object have to have before it loses its capacity for self-propelled motion? Does a stone thrown into the air possess this attribute? Presumably it does, but not in the required sense. And if motion through the air is not self-propelled, is [ability to fly] thereby precluded? Consider the case of gliders and hot air balloons. Secondly, how fast does an object have to move before its motion can be described as fairly rapid? Does a hot air balloon satisfy this requirement? Finally, for how long does an object have to be airborne, and what distance does it have to be from the ground, for one to be able to say that it moves through the air? Does an athlete doing the high jump qualify? To what extent, then, can one say that gliders, hot air balloons, stones thrown into the air, and jumping athletes exhibit the attribute [ability to fly]?

Soos hierdie voorbeeld toon, kan definiërende kenmerke self gradeerbaarheid, vaagheid van toepassing en selfs 'n prototipiese struktuur vertoon, m.a.w. al poneer mens vir ' $n$ kategorie 'n versameling definiërende attribute, waarborg dit nie dat die bepaling van lidmaatskap in 'n kategorie 'n eenvoudige saak sal wees nie.

\subsection{3 'n Leksikografiese perspektief}

Uit die bespreking in Zgusta (1971: 27 e.v.) blyk dit dat Zgusta in sy uitgangspunt by die klassieke kategoriebeskouing aansluit en dat hy hierdie kategoriemodel as model vir alle leksikale items aanvaar, ongeag of hulle polisemies of monosemies is.

Oor die ontstaan van leksikale kategorieë meld hy:

Obviously, the human mind is capable of abstracting from many individual and different occurrences of a "thing" a general notion also new occurrences of the members of the class. Such a notion is, then the designatum, a component of the lexical meaning of a word. (Zgusta 1971: 28)

Ten opsigte van die designatum is die leksikograaf se taak om die definiërende kenmerke ("criterial features") te abstraheer wat die designatum konstitueer:

The designatum can be visualized as consisting of the criterial features, corresponding to these criterial qualities, both if it pertains to a part of the material world and if it does not.

A good part of the lexicographer's research is concerned with establishing criteriality, with the task to find what is criterial and what is 
not, with the necessity to discover the criterial features as precisely as possible. (Zgusta 1971:29)

Hierdie definiërende kenmerke vorm die basis vir ons oordeel of ' $n$ bepaalde voorwerp met ' $n$ betrokke leksikale item benoem kan word (Zgusta 1971: 28-29) (of tot die betrokke kategorie gereken kan word). Ter illustrasie: vir die gebruik van table is die definiërende kenmerke dat "the respective piece of furniture must form a flat, roughly horizontal surface on which things can be put and which is supported by one or more legs " (1971: 29). Hierdie kenmerke vorm die kernbetekenis van ' $n$ kategorie en geld as sodanig vir alle lede van die kategorie.

Afwykende betekeniswaardes word in terme van afwykinge van die versameling definiërende kenmerke/kernbetekenis gedefinieer, maar alle betekenisonderskeidinge "have the criterial qualities of their designata and vary only in the non-criterial respects " (Zgusta 1971: 48). Die aanvaarding van 'n kernbetekenis vir al die lede van 'n kategorie bring dan ook noodwendig mee dat hoe meer uiteenlopend die lede van ' $n$ kategorie is, hoe abstrakter en vaer die designatum daarvan moet wees om sodoende al die lede te akkommodeer. Hierdie punt word geillustreer deur Zgusta (1971) se verduideliking van die status (figuurlik of nie) van die gebruik van bondage in die uitdrukking the years of my bondage as verwysing na 'n ongelukkige huwelik:

The answer to this question depends on how we conceive the designatum of the word bondage: if we conceive it so that the subject's being a slave or a serf or tenant is criterial to it, then we have here a case of the figurative use, because the unhappy husband was neither a slave, nor a serf, nor a tenant of his wife. If, on the other hand, we do not conceive this as criterial for the designatum, then the designatum necessarily becomes much broader and the actual signification of the expression quoted, occasional as it is in this application, can be conceived as corresponding to the normal meaning as established in the system; if we accept this position we should probably classify this case as a contextual nuance. (Zgusta 1971:52)

Die assimilasie van nuwe betekenisonderskeidinge tot ' $n$ kategorie lei dus tot verdere veralgemening van die designatum/kernbetekenis van 'n kategorie. Vgl. die volgende:

What if the joke about bondage is frequently repeated? The new application will tend to become a part of the system. What if there are many similar cases of such applications, say bondage in reference to the blind love to a woman, in reference to the fanatical subservience to an idea or so? We will tend, in that case, to conceive the 
designatum as broader, with less specific criterial features. (Zgusta 1971:53)

Ten spyte van die aanvaarding van die klassieke kategoriemodel as uitgangspunt vir leksikale kategorieë voeg Zgusta (1971: 29-32) ook allerlei kwalifiserin. ge aan sy opvatting van klassieke kategorieë toe, in die besonder wat die status van die definiërende kenmerke betref. Zgusta wys daarop dat

daar geen universele inventaris definiërende kenmerke bestaan wat vir alle tale geld nie;

wat definiërend in een taal is, dit nie noodwendig ook in 'n ander taal is nie; en

aspekte van die buitelinguistiese wat in een taal definiërend is, dit nie noodwendig ook in ' $n$ ander taal is nie.

Die aanvaarding van die taak van die leksikograaf as die soeke na definiërende kenmerke impliseer egter nie dat Zgusta (1971) hom in beginsel of uitsluitlik tot die strukturalistiese semantiek as teoretiese raamwerk verbind nie. In hierdie verband wys hy daarop dat

... the lexicographer will be well advised not to be too much impressed by the basic uncertainty concerning the nature of lexical meaning. The problem of the nature of meaning is certainly broader than the lexicographer's tasks; it is probably even broader than the purely linguistic investigation, since it requires a combination of linguistic, psychological, philosophical, and other approaches. The lexicographer's activity, however, can be conceived as a rather pragmatic one, at least in this respect. (Zgusta 1971: 24)

Met die voorafgaande spel Zgusta as 't ware 'n konseptualisering uit van hoe die leksikografiese metateorie noodwendig daar sal uitsien: gegee die basiese onsekerhede oor die aard van leksikale betekenis en die veelheid van perspektiewe van waaruit betekenis noodwendig benader moet word, sal die leksikograaf hom nie wesentlik met teoretiese probleme bemoei nie, maar vanuit die praktyk self, in die besonder die problematiese aspekte van die betekenisdata, op eklektiese wyse omgaan met wat teoreties aan bod is. Die feit dat hy in die aansluiting by 'n semantiese raamwerk hom ook nie uitsluitlik op die strukturalisme rig nie, blyk uit sy persoonlike voorkeur, "which is a rather psychological one" (Zgusta 1971: 24). Hierdie uitgangspunt word veral gemanifesteer in die wyse waarop Zgusta in sy uiteenisetting voortdurend bewus is van die konseptuele digotomieë in die teoretiese apparatuur van die leksikograaf en die wyse waarop die semantiese data nie altyd netjies in sulke rigiede klasse en entiteite verdeel kan word nie. In hierdie verband onderskei hy as 't ware tussen die ideaal-tipiese uitgangspunt (wat in sommige gevalle wel direk in die data 
weerspieël word) en die minder ideale gevalle (of minder prototipiese gevalle) waar digotomiese teoretiese uitgangspunte en die vae, skalêre aard van die data nie bymekaar uitkom nie. Vergelyk bv. Zgusta (1971:54):

The lexicographer will be well advised to have the contradistinction systemic :: occasional as sharply distinguished as possible, in his notional framework. On the other hand, the lexicographer would probably mishandle his data if he tried to treat them with a greater degree of distinctive precision than that which is inherent in the facts of language. It is a fact that the usage vacillates around a focus of what is most usual (and it is this focus which is considered the norm).

Die gaping tussen teorie en praktyk wat dikwels aan die leksikografie toegeskryf word, kan mens dan ook na hierdie feit toe terugvoer, nl. dat die beskikbare teoretiese apparaat, en dan in die besonder die klassieke kategoriemodel, nie die feite van taalgebruik kan verreken nie.

Een belangrike uitvloeisel vir die leksikografie van die bespreking in 2.2.2 is die onhoudbaarheid van 'n leksikale semantiek wat as "suiwer linguisties" gekonsipieer word. In KS word daarenteen 'n leksikale semantiek aanvaar wat breedweg as "ensiklopedies" bestempel kan word. Aangesien hierdie besondere opvatting van die leksikale semantiek 'n groot deel van die bespreking hierna onderlê, word daar eers op enkele aspekte van hierdie teorie ingegaan.

\subsubsection{Leksikale semantiek - ' $n$ kognitiewe alternatief}

Teen die agtergrond van die voorafgaande word daar in KS aanvaar dat die betekenis van ' $n$ leksikale item slegs relatief ten opsigte van (' $n$ ) bepaalde kognitiewe domein/domeine ${ }^{14}$ gedefinieer kan word. Die konseptualisering van die leksikale item doelskop vooronderstel bv., as een van die kognitiewe domeine daarvan, 'n groot hoeveelheid kennis wat met die reëls en doelstelling van

Komplekse kognitiewe domeine oorvleuel na inhoud en struktuur met entiteite wat ander navorsers met terme soos frames, scripts, schemata, scenes, scenarios, geïdealiseerde kognitiewe mod elle, ens. aandui. Taylor (1989:87) onderskei in hierdie verband soos volg:

In the following, 'frame' will refer to the knowledge network linking the multiple domains associated with a given linguistic form. We can reserve the term 'script' for the temporal sequencing and causal relations which link events and states within certain action frames.

en, in navolging van De Beaugrande en Dressler:

frames constitute 'global patterns' of 'common sense knowledge about some central concept', such that the lexical item denoting the concept typically evokes the whole frame. In essence, frames are static configurations of knowledge. Soripts, on the other hand, are more dynamic in nature. Typically, scripts are associated with what we have referred to earlier as vasic level events such as 'do the washing up' and 'visit the doctor', which are structured according to the expected sequencing of subordinate events. (Taylor 1989: 87-88) 
rugby verband hou; die betekenis van elmboog word deels gekarakteriseer deur die posisie daarvan binne die oorkoepelende konfigurasie van die menslike arm; die begrip April kan slegs gedefinieer word teen die agtergrond van die komplekse begrip van maandsiklusse wat ' $n$ jaar verdeel.15

Daar bestaan ook geen vaste of universele versameling kognitiewe domeine nie - enige faset van ons mentale ervaring of konseptuele wêreld kan potensieel in hierdie funksie optree. Langacker (1988b: 56) gee die volgende voorbeeld: die woord flits denoteer 'n kort, intense en moontlik diffuse ligsensasie. Vir die beskrywing van die betekenisstruktuur van hierdie leksikale item moet daar dus verwys word na tyd, kleurruimte (veral die graad van helderheid) en die omvang van die visuele veld. Sommige leksikale items hou verband met omvattende, selfs oop matrikse. Die karakterisering van die betekenisstruktuur van mes vereis bv. verwysing na die vorm daarvan (tipiese vorms van messe), wat die domein van ruimte vooronderstel; die funksie van ' $n$ mes as instrument om mee te sny; die opvatting van tipiese snyhandelinge; die grootte en gewig van messe; die vervaardigingsmateriaal; kulturele assosiasies met messe, ens. Die bindende element in al hierdie diverse domeine is die rol wat die gedenoteerde entiteit van mes in almal van hulle speel.

So ' $n$ ensiklopediese benadering bring egter ook 'n demarkeringsprobleem mee omdat mens bv. nie sou wou aanvaar dat alles wat ' $n$ individu oor honde weet ewe relevant vir sy konsep HOND is nie. In KS word daar wel aanvaar dat die gekonvensionaliseerde betekenisonderskeidinge van 'n leksikale item elkeen ' $n$ bepaalde profielstelling (afbakening) is binne so 'n kennisdomein (matriks).16 In beginsel kan enige stukkie kennis, selfs die mees bisarre, in 'n

Hierdie standpunt staan in teenstelling met dié van die relasionele strukturalisme wat aanvaar dat die betekenis van 'n leksikale item gedefinieer word deur die relasies wat dit met ander leksikale items onderhou (vgl. Lyons 1977).

Ander kenmerke van kognitiewe domeine is die volgende:

(i) Kognitiewe modelle is nie amorfe konstrukte nie maar besit interne struktuur (proposisionele, beeldskematiese, metaforiese modelle en metonimiese modelle) (vgl. Lakoff 1987).

(ii) Sommige kennisdomeine is linguisties meer relevant as ander; die relevansie van 'n domein/domeine (of onderdele daarvan) kan egter varieer na gelang van die konteks. Enige so in domeinverandering kan tot betekenisveranderinge lei of die grond vir betekenisvariasie wees.

(iii) Kennisdomeine is geïdealiseerde, kognitiewe modelle: hulle verteenwoordig idealiseringe (abstraksies) van die waargenome/ervaarde, is die produk van menslike ervaring en as sodanig deel van die mens en hulle dien op verskillende vlakke as modelle vir kategorisering en argumentasie ( $v$ gl. Lakoff 1987).

Epistemologies gesien word daar in KS aanvaar dat konseptuele kategorieë nie objektiwisties nie maar eksperensieel van aard is. Daarmee word aangeneem dat konseptuele kategorië̈ nie eenvoudig afspieëlings is van kategorieë wat objektief in die wêreld, los van die mens bestaan nie, maar direk ingegee word deur aspekte van die menslike psigologie en daarom 
kognitiewe domein opgeneem word, solank as wat hierdie assosiasie deur 'n voldoende aantal mense aanvaar word. Die vraag is dus nie waar die lyn tussen linguistiese en ensiklopediese kennis getrek moet word nie, maar wat in enige taalgemeenskap as gekonvensionaliseerde kennis beskou kan word (Taylor 1989: 89). Daar word dus aanvaar dat die agtergrondskennis vir die beskrywing van woordbetekenisse 'n netwerk van gedeelde, gekonvensionaliseerde en selfs in 'n mate geidealiseerde kennis uitmaak wat gewortel is in kulturele opvattinge en gebruike.

Gegee die definiërende aard van omvattende domeine word daar aanvaar dat die betekenis of kennis van die betekenis van een leksikale item, soos tandeborsel, nie afhanklik is van die bestaan van of kennis van ander leksikale items nie, soos bv. haarborsel of vloerborsel - 'n leksikale item soos tandeborsel kry sy betekenis uit die rol wat tandeborsels in mondhigiëne speel en nie van paradigmatiese kontraste met ander lede in die sisteem nie. Die begrip TANDEBORSEL het m.a.w. niks te make met die manier waarop mense hulle hare of vloere borsel nie (vgl. Taylor 1989: 80-81).

'n Linguistiese item kry die betekenis daarvan deur 'n spesifieke deel of konfigurasie in die relevante domein te profileer of uit te lig. Profilering behels die strukturering van ' $n$ domein met behulp van 'n bepaalde skema of versameling sodanige skemas. Ons sal sê dat enige leksikale item so 'n skema op 'n domein afdruk. Ter illustrasie: die konsepte WEEK, DAG en MAANDAG kom na vore as ' $n$ bindende skema wat sekere dele in die domein van tyd profileer of afbaken. ' $n$ Opeenvolgingskema struktureer die konsep WEEK in 'n opeenvolging van diskrete entiteite (dae).

Die betekenis van sommige leksikale items, soos op en af, kan mens verduidelik deur verwysing na 'n enkele domein; die betekenis van ander leksikale items vereis egter gelyktydige verwysing na verskillende domeine. Ter illustrasie: die betekenis van gholfbal vereis verwysing na die vorm daarvan (gholfballe is gebonde entiteite in ' $n$ driedimensionele ruimte) sowel as die kleur, grootte, materiaal, ens. daarvan. Maar die volledige verstaan van die betekenis van hierdie woord vereis ook verwysing na die reëls en aktiwiteite van die spel gholf (vgl. Taylor 1989: 85).

Aangesien sommige van hierdie domeine meer prominent as ander kan wees, onderskei Langacker (1987) verder tussen primêre en sekondêre domeine. In die gewone betekenis van die woord sout is die domein van kos die primêre domein: sout is 'n substansie wat by sekere voedselsoorte gegooi word om die smaak daarvan te verbeter. Die chemiese samestelling daarvan is in hierdie sin slegs van sekondêre belang.

nie los van hierdie ervaringskontekste bestudeer kan word nie. Een van die belangrike uitvloeisels van hierdie anti-objektiwistiese uitgangspunt is dat denotasie gesien word as die relasie tussen 'n leksikale betekenisstruktuur en 'n ervaringsgebaseerde konseptuele kognitiewe domein (nie die werklikheid nie) (vgl. Lakoff 1982: 99; Geeraerts 1989a: 344-345). 
Volgens Lakoff (1987) moet die betekenis van 'n woord soos moeder bv. teen ten minste vyf sulke domeine verstaan word, $\mathrm{nl}$. die genetiese domein: ' $n$ moeder is ' $n$ vroulike persoon wat genetiese materiaal aan die kind gee; die geboortedomein: ' $n$ moeder is die persoon wat geboorte aan die kind skenk; die voedingsdomein: 'n moeder is die een wat ' $n$ kind voed en grootmaak; die genealogiese domein: ' $n$ moeder is die naaste bloed verwant; en die huweliksdomein: ' $n$ moeder is die vrou van die man.

Al vyf hierdie domeine is dan ook relevant in die wyse waarop ' $n$ woord soos moeder van vader verskil en nie, soos die strukturaliste aanvoer, net die kenmerke [+MANLIK] en [-MANLIK] nie.

Ter illustrasie: die vyf domeine van moederskap hier bo vorm die moeder-"raam" waarin hierdie domeine saamval: hiervolgens het die moeder ' $n$ seksuele verhouding met die vader, raak verwagtend, skenk geboorte aan die kind, en voed hom en maak hom groot, terwyl sy met die vader getroud bly. So 'n scenario is natuurlik hoogs geïdealiseerd vir sover dit van die nie-tipiese instansiërings van moeders abstraheer (bv. surrogaatmoeders, moeders wat kinders aanneem, enkelmoeders, werkende moeders, ens.), maar dit is teen hierdie model wat die prototipiese moeder gedefinieer word. Ander nie-tipiese instansiërings vorm met ander woorde periferale lede van die kategorie MOEDER soos hier bo gedefinieer. So ' $n$ kognitiewe domein beliggaam uiteindelik diepgesetelde opvattinge oor die rol en funksie van die gesin in in gemeenskap, wat vir sommige as die norm vir die kategorie as sodanig kan geld. Ander kan hierdie raam/kognitiewe model natuurlik verwerp. Enige so ' $n$ model kan inhoudelik met die tyd verander en dit hoef nie noodwendig wetenskaplik geverifieerde kennis van die wêreld in te sluit nie.

Die voorafgaande uitgangspunte oor die aard van leksikale betekenis is in die eerste plek van besondere belang vir die begronding van ' $n$ teorie van die leksikografiese definisie. Dit open 'n perspektief waarin sowel linguistiese as ensiklopediese kenmerke in definisies gelegitimeer word. Die uitgangspunt vir definisies is met ander woorde die omvattende konseptuele strukture wat sprekers op konvensionele wyse met leksikale items assosieer. ' $n$ Soeke na die definiërende kenmerke van 'n leksikale kategorie, soos gedefinieer in die klassieke kategoriemodel hier bo, word dus verwerp.

Omgekeerd bied die voorafgaande ' $n$ breër verwysingsveld as die binêre, komponensiële ontledingstegniek vir die ontleding van die inhoud, die verwantskappe en verskille van die definisies wat daar in woordeboeke ter beskrywing van die verskillende betekenisonderskeidinge van 'n leksikale item geponeer word - in die besonder dan ook dat betekenisverwantskap in die geval van leksikale items as sodanig binne die raamwerk van konseptueel-kog- 
nitiewe kennisdomeine benader kan word. Hierdie uitgangspunte legitimeer m.i. alreeds die bestaande leksikografiese definisiepraktyk waarin daar kenmerke uit die verskillende relevante kognitiewe domeine vir die definiëring van die verskillende betekenisonderskeidinge van ' $n$ woord betrek word. ' $n$ Paar eenvoudige voorbeelde ter illustrasie:

In NWB word daar die volgende geënkapsuleerde definisie van sout gegee waarin die eerste betekenisonderskeiding teen twee kognitiewe domeine (en nie bv. teen ander soorte water of ander soorte chemiese middele nie) gedefinieer word, nl. ons kennis van seewater as soutwater en die ekstraksie van sout uit seewater, en ons kennis van die gebruik van sout as smaakmiddel:

1. chemiese bestanddeel wat aan seewater sy kenmerkende smaak gee, veral die gekristalliseerde vorm hiervan verkry deur verdamping; kombuissout, toegevoeg aan kos om die smaak te verbeter.

'n Tweede voorbeeld: Die woord moeder word NWB in die eerste betekenisonderskeiding slegs teen die genealogiese model gedefinieer as "1. ma. Die van vier kinders". As tweede betekenisonderskeiding word gegee "2. oorsprong, bron", wat 'n betekenisverbreiding binne die genealogiese domein is. HAT gee by laasgenoemde die voorbeeldsin Ledigheid is die moeder van alle kwaad.

Naas bogenoemde twee betekenisonderskeidinge word daar in HAT ook 'n derde uitgesonder, nl. 'Vrou wat soos 'n moeder sorg", wat weer 'n betekenisverbreiding is binne die voedings-/versorgingsdomein. Laasgenoemde vooronderstel egter ' $n$ betekenisonderskeiding van moeder as "die een wat haar gebore kinders versorg", maar wat nie in een van die twee woordeboeke opgeneem is nie.

Vgl. in hierdie verband ook die definisies in HAT en NWB van bv. vader en week, ${ }^{17}$ waaruit die praktyk duidelik blyk dat daar alreeds in die leksikografie teen die agtergrond van breër gekonsipieerde kognitiewe domeine gedefinieer word.

\section{Prototipekategorieë}

Teenoor die model van klassieke kategorieë staan die model van prototipekategorieë (afgekort: PTKe), waarvan die interne struktuur en kognitiewe begronding die hoofondersoeksobjek van KS vorm.

17 Die implikasies van die uitgangspunte van die $\mathrm{KS}$ vir die leksikografiese definisie is 'n veel omvattender onderwerp wat nie hier verder aandag sal kry nie. In die besonder sou mens ook op die pragmaties-funksionele oorweginge en beperkinge moes ingaan wat aan die leksikografiese definisie opgelê word. 
'n Vinnige blik laat blyk dat PTKe feitlik in elke opsig van klassieke kategorieë verskil. Die volgende word bv. as kenmerke van PTKe geponeer: vae grense tussen kategorieë (en intern tussen lede van kategorieë); verskille in die prominensie van attribute ${ }^{18}$ en graad van lidmaatskap in die kategorie; relasies van analogie en oorkoepelende ooreenkoms tussen die alternatiewe betekenisonderskeidinge; en 'n trossing van betekenisonderskeidinge of betekenistoepassinge rondom sentrale gevalle (prototipes) wat omring word deur minimaal afwykende periferale gevalle.

In sy uiteensetting van betekenisvariasie in taalgebruikskontekste vertoon Zgusta (vgl. Zgusta 1971: 36-74) 'n besondere sensitiwiteit vir juis die bogenoemde kenmerke van polisemiese kategorieë, en dan in die besonder vir die probleme wat dit veroorsaak as mens met 'n klassieke kategoriekonsepsie en digotomies en rigied afgebakende teoretiese begrippe poog om betekenisvariasie te verantwoord. Hy beklemtoon telkens die vaagheid van grense tussen betekenisonderskeidinge en funkies van leksikale items (vgl. Zgusta 1971: 36-38); die vaagheid in oordele oor die status van betekenisonderskeidinge (bv. oor die interpretasie van ' $n$ betekenisonderskeiding as synde letterlik of figuurlik; vgl. Zgusta 1971: 52); die stabilititeit, maar dinamiese plooibaarheid, van polisemiese kategorieë, d.i. hulle aanpassingsvermoë om aan nuwe stilistiese behoeftes en behoeftes aan benoemingsmoontlikhede te voldoen (vgl. Zgusta 1971: 54-55); die onmoontlikheid om oorkoepelende definisies vir alle polisemiese kategorieë te definieer (vgl. Zgusta 1971: 66); en die inherente strukturering van 'n kategorie in terme van dominante en minder dominante lede (vgl. Zgusta 1971: 65-66). Verder gee Zgusta (1971: 275-282) uitgebreid aandag aan die sg. "lineariteitsprobleem", d.i. die probleme waarvoor die leksikograaf te staan kom as hy poog om die wesentlik multidimensionele semantiese struktuur van leksikale kategorieë in 'n geskrewe woordeboekartikel weer te gee.

In die uiteensetting van hierdie problematiese gegewe van polisemiese kategorieë hou Zgusta egter voortdurend die pragmatiese voor oë, d.i. die feit dat die leksikograaf bepaalde besluite moet neem met die oog op die samestelling van die woordeboek (en uiteindelik ook die vereistes wat daaraan deur gebruikers gestel word). Zgusta (1971: 64) meld in hierdie verband bv.:

The lexicographer will see in his practice that the single senses (usually with the exception of the terminological ones) overlap or that there are many borderline cases ... But though it is an error if the lexicographer tries to make the single senses more sharply distinguished from each other than is indicated by the data, the establish-

As mens dus wel van attribute praat in die prototipeteorie word daarmee nie die atomiese semantiese komponente van die klassieke teorie bedoel nie, maar wel die dimensies op grond waarvan entiteite vir identiteit/ooreenkoms beoordeel word. Attribute beliggaam in hierdie sin "the commonality (that speakers) perceive in arrays of fully specified, integrated units" (Langacker 1987: 22). 
ment of the single senses and their organization are, on the other hand, among the lexicographer's cardinal tasks.

Zgusta (1971) maak op verskeie plekke die punt dat die leksikograaf hom in sy ontleding en aanbieding van die data nie deur sy teoretiese raamwerk moet laat mislei nie. In die besonder ten opsigte van polisemie:

The first of these dangers is that the lexicographer might try to put all his data into the pigeonholes of the categories which were discussed above, disliking the idea that there are always borderline cases. Worse than that, he might try to posit only a few patterns of polysemy and then try to arrange all his data in all his items only according to these few schemes. (Zgusta 1971: 66)

En:

He will know that the single direct and figurative senses of some words can be put into contradistinction with sufficient clarity, while they overlap in the case of other words. In short, the lexicographer will know that the variety of patterns in which the polysemous meaning of the lexical units can be organized is caused not only by the presence or absence of different properties and by their different combinations, but also by the fact that the same quality can be present in different words in widely differing degrees. (Zgusta 1971: 67)

En:

The situation, its description and presentation is frequently even more difficult, because the applications form a continuum with observable peaks but unclear boundaries. (Zgusta 1971: 74)

Die kernpunt ten opsigte van die voorafgaande is egter dat Zgusta nie self ' $n$ omvattende en koherente linguistiese teorie ontwikkel n.a.v. die problematiese empiriese gegewe nie, of in besondere diepte op elkeen van hierdie probleemverskynsels ingaan nie. En dit is dan juis in hierdie opsig dat die KS as teoretiese alternatief en begronding aangebied word.

Gegee dat polisemiese kategorieë in KS as prototipekategorieë ontleed word, word daar in die onderstaande gepoog om die kenmerke van hierdie kategorieë nader te ekspliseer. Hierdie kenmerke vra om sistematiese uiteensetting omdat (i) nie alle prototipekategorieë in gelyke mate al die onderstaande kenmerke vertoon nie, d.i. onderstaande kenmerke kan nie as ' $n$ versameling afdoende en noodsaaklike kenmerke vir PTKe beskou word nie; en (ii) nie 
alle kategorieë wat prototipe-effekte vertoon, nie intuitief as polisemies beskou word nie.

\subsection{Hoofkenmerke}

Geeraerts (1989b) gee uitgebreid aandag aan die vier hoofstruktuurkenmerke wat aan prototipiese kategorieë toegeskryf word (en waarin dit van klassieke kategorieë verskil). Die vier kenmerke is die volgende:

(i) Prototipekategorieë kan nie gedefinieer word met behulp van in enkele versameling definiërende, d.i. noodsaaklike en afdoende kenmerke nie.

(ii) Prototipekategorieë vertoon 'n familieverwantskapstruktuur. In die algemeen gestel neem hulle struktuur die vorm aan van 'n speekkategorie ("radial set"), bestaande uit geklosterde en oorvleuelende betekenisonderskeidinge, -nuanses en -toepassinge.

(iii) Prototipekategorieë vertoon grade van kategorielidmaatskap - nie elke lid is ewe verteenwoordigend van die kategorie nje.

(iv) Prototipekategorieë het vae grense. (Vgl. Geeraerts 1989b: 592-593.)

\subsubsection{Afwesigheid van 'n oorkoepelende definisie}

Die eerste kenmerk verwys na die feit dat dit in die geval van prototipekategorieë nie moontlik. is om 'n oorkoepelende definisie te gee wat al die onderskeie betekeniswaardes daarvan ondervang nie. Hierdie feit word die duidelikste geillustreer indien ' $n$ leksikale kategorie op die intensionele vlak naas een of meer letterlike betekenisonderskeidinge, ook een of meer figuurlike of metaforiese betekenisonderskeidinge vertoon. Ter illustrasie: die woord kat het onder meer die volgende betekenisonderskeidinge: "klein, viervoetige huisdier wat muise vang" en "snipperige, naywerige vrou" (vgl. NWB). Die uiteenlopende aard van die twee betekeniswaardes bring mee dat daar nie 'n enkele oorkoepelende definisie gegee sou kon word wat altwee hierdie betekenisonderskeidinge ondervang nie, alhoewel hulle op grond van semantiese verwantskap tot 'n enkele leksikale item kat gereken word.

Pogings om so 'n oorkoepelende definisie vir al die lede van 'n PTK op te stel, is meestal nie suksesvol nie omdat

(i) die geisoleerde kembetekenis gewoonlik nie algemeen genoeg is om van alle betekenisonderskeidinge, -nuanses en -toepassinge van in leksikale item rekenskap te kan gee nie, en/of

(ii) die kembetekenis nie spesifiek genoeg is om die betrokke leksikale item uniek van ander leksikale items in ' $n$ taal te onderskei nie;

(iii) daar in die soeke na kernbetekenisse geabstraheer word van die tussenliggende betekeniswaardes van 'n leksikale item, d.i. dié 
betekeniswaardes wat nie binne die grense van die skerp afgebakende betekenisonderskeidinge val nie maar die oorgange tussen betekeniswaardes enkapsuleer;

(iv) daar geabstraheer word van wesentlike semantiese kenmerke waar sonder mens nie rekenskap kan gee van die seleksiebeperkinge op leksikale items nie;19

(v) daar slegs 'n definisie verskaf word van die prototipe van 'n kategorie of die sentrale betekenisonderskeiding, met verontagsaming van die meer periferale lede/betekenisonderskeidinge. ${ }^{20}$

Gegee die kritiek op die soeke na afdoende en noodsaaklike kenmerke, volg dit ook dat watter kenmerke ook al in definisies ter sake gestel word, hulle nie as noodsaaklik en afdoende beskou kan word nie.

In die geval van PTKe berus verwantskap van lede nie op identiteit nie maar op analogie, d.i. gedeeltelike identiteit of ooreenkoms (Geeraerts 1987b: 280). Langacker (1988d: 133-134) beklemtoon ook hierdie feit in sy beskrywing van die kategoriebeskouing wat die prototipeteorie onderlê:

Because there is no specific checklist of criterial features, membership in a category is not subject to absolute predictability (indeed, there need be no significant features that are shared by all class members). Whether an entity qualifies depends on the judgement of the categorizer, and his tolerance in accepting members that diverge from the prototype. There is no fixed limit on how far something can depart from the prototype and still be assimilated to the class, if the categorizer is perceptive or clever enough to find some point of resemblance to typical instances.

Dirven en Taylor (1988) gee die volgende voorbeeld: die ongrammatikaliteit/onaanvaarbaarheid van die uitdrukking ${ }^{* 1} n$ hoë sigaret kan nie herlei word na enige eienskappe van die item hoog nie, maar is die resultaat van ons daaglikse ervaring van (en dus ons konseptualisering van) sigarette as gestalt-objekte. Ons verwys bv. na 'n lang sigaret ongeag of 'n sigaret in 'n horisontale of vertikale posisie gehou word. Sigarette word dus wesentlik in hulle dimensie as lang of kort entiteite gekonseptualiseer en die beperkinge op die gebruik van 'n leksikale item volg direk uit so 'n geassosieerde en gekonvensionaliseerde kognitiewe struktuur (vgl. Dirven en Taylor 1988: 394).

Wierzbicka (1990) volg in haar kritiek op die "misbruik" van die begrippe "prototipe" en "prototipisiteit" onder meer hierdie strategie om aan te toon dat dit moontlik is om (in sommige gevalle altans) afdoende en noodsaaklike definisies vir PTKe te gee. Volgens Geeraerts (1989 b: 602) word die afwesigheid van noodsaaklike en afdoende definisies (wat die plooibare toepassingsmoontlikhede van kategorieë konstitueer) in gevalle soos hierdie egter omseil deur op die prototipiese kern van in kategorie te konsentrees en om die probleem van die geklosterde en speekaard van polisemiese leksikale items te ornseil. 
Soos reeds hier bo vermeld, beklemtoon Zgusta (1971) die feit dat vir bepaalde polisemiese kategorieë daar geen oorkoepelende definisie formuleerbaar sou wees nie. In die leksikografiese praktyk vind mens dan ook dat daar eerder oormatig tussen die verskillende betekenisonderskeidinge gedifferensieer word, maar andersyds ook dat die strewe na ekonomie in baie gevalle lei tot die opstel van disjunktiewe definisies, d.i. definisies waarin verskillende betekenisonderskeidinge, -toepassinge en -nuanses as 'n disjunksie van betekeniswaardes in ' $n$ enkele definisiesin saamgevat word wat soms, maar soms nie, deur kommas en/of kommapunte van mekaar geskei word.

'n Illustrasie hiervan is bv. die eerste betekenisonderskeiding wat in WAT by hersiening verskaf word, nl. "handeling, proses van te hersien; verbetering, wysiging; herhaling; revisie". So 'n definisie bestaan nie eenvoudig uit 'n konjunksie van sinonieme of ' $n$ versameling definiërende attribute nie, maar die verskillende attribute verwys na subtiele semantiese verskille wat nie elkeen aanwesig is by die onderskeie voorbeeldsinne wat by hierdie enkele definisiesin verskaf word nie:

' $n$ Saak in hersiening neem. Hersiening van voorraad. Hersiening van ' $n$ wetsbepaling of vonnis. Hersiening van ou lesse. Grondwets-, tarief-, wetshersiening.

Wat in gevalle soos hierdie binne die bestek van 'n enkele definisiesin saamgevat word, korrespondeer dus nie met 'n enkele oorkoepelende definisie vir die kategorie as 'n geheel nie.

Dat sulke geponeerde oorkoepelende definisies as onadekwate beskrywing vir die onderskeie lede van kategorieë aangevoel word, word duidelik geillustreer (al sy dit hier 'n geval van 'n semanties leë werkwoord) in die wyse waarop verdere semantiese opheldering of presisering naas die oorkoepelende definisie in die beskrywing van hersien (ww.) in WAT verskaf word. Vgl.:

Opnuut bekyk ten einde moontlike foute en gebreke te ontdek en te verbeter.

Meer bep. a. Nasien; verbeter; revideer ...

b.Noukeurig nagaan of iets nog a/d vereistes of behoeftes voldoen en dit dan daarmee in ooreenstemming bring; verander, wysig ... c. (onderwys) [Reeds behandelde leerstof] weer noukeurig deurwerk $\mathrm{m} / \mathrm{d}$ oog op 'n eksamen; herhaal.

In WAT is dit bv. praktyk om sulke pogings tot oorkoepelende definisies te presisieer met meer spesifieke betekenisonderskeidinge wat ingelui word met frases soos "meer bepaald", "enigeen van", "enigeen van die soorte van die geslag", ens. 


\subsection{2 'n Familieverwantskapstruktuur}

Die tweede kenmerk geld ten opsigte van die semantiese relasie tussen die verskillende betekenisonderskeidinge van 'n leksikale item. Eerder as om te aanvaar dat die verwantskap van die lede/betekenisonderskeidinge van 'n PTK berus op die deel van dieselfde/identiese semantiese kenmerke, word geponeer dat hulle 'n familieverwantskap vertoon. Rosch en Mervis (vgl. Geeraerts 1988c: 344) verduidelik hierdie begrip soos volg:

A family resemblance relationship takes the form $A B, B C, C D, D E$. That is, each item has at least one, and probably several, elements in common with one or more items, but no, or few, elements are common to all items.

Vertaal in terme van die betekenisonderskeidinge, -nuanses en -toepassinge van 'n polisemiese kategorie impliseer dit (i) dat nouverwante betekenisonderskeidinge nie al hulle definiërende kenmerke met mekaar gemeen het nie (in welke geval hulle identies sou wees), maar net een of meer kenmerke deel; (ii) dat nouverwante betekenisonderskeidinge of -toepassinge meer kenmerke met mekaar deel as die wat verder van mekaar verwyder is in ' $n$ afleidingsreeks.

Hou ons eers by die formule hier bo, dan word daarmee aangetoon dat die naasliggende betekenisonderskeidinge $A B$ en $B C$ die kenmerk $B$ deel, maar die periferale betekenisonderskeiding $D E$ en die eerste betekenisonderskeiding $\mathrm{AB}$ geen kenmerke met mekaar deel nie. Toegepas op die polisemiese geskakeerdheid van kat: tussen die betekenisonderskeidinge "klein, viervoetige huisdier wat muise vang" ," wilde dier van die kattegeslag" en "ramkat" is daar 'n groter mate van betekenisooreenkoms as tussen enige van hierdie onderskeidinge en die periferale, metaforiese betekenisonderskeiding "snipperige, naywerige vrou".21

Die tweede kenmerk wat uit die familieverwantskapstruktuur van PTKe spruit, is dat naasmekaarliggende betekenisonderskeidinge/lede mekaar kan

Daarmee word nie geimpliseer dat daar tussen sommige van die betekenisonderskeidinge van 'n polisemiese kategorie geen (semantiese) verwantskap bestaan nie. In so 'n geval sou mens met homonimie te make hè, al is die grens tussen polisemie en homonimie self dikwels vaag. In die geval van die relasie tussen 'n letterlike betekenisonderskeiding en ander betekenisverbreidings (soos metaforiese, metonimiese en selfs "idiomatiese verbreidinge") is daar wel deeglik sprake van ooreenkoms of verwantskap, alhoewel die basis van hierdie verwantskap bv. nie eksplisiet in woordeboekdefinisies of -artikels omskryf word nie. Die kernpunt is dat verwantskap gebaseer is op afdoende ooreenkoms (familieverwantskap) eerder as op identiteit. Kernbetekeniskomponente van sentrale lede kan minder prominent of afwesig wees by periferale lede (vgl. metaforiese relasies). Metonimie berus verder nie op ooreenkoms nie maar op konseptualiseringe van aaneengrensing. $\mathrm{Vgl}$. in hierdie verband ook die bespreking in Swanepoel (1990). 
oorvleuel, d.i. vae grense het, omdat hulle een of meer kenmerke met mekaar kan deel, soos duidelik behoort te blyk uit die drie letterlike betekenisonderskeidinge van kat hier bo.

'n Kenmerk van die familieverwantskapstruktuur is dat die relasie tussen naasliggende betekenisonderskeidinge daarin belig word:22 elke betekenisonderskeiding of -nuanse word dus gesien in terme van die rélasie daarvan tot ' $n$ voorafgaande betekenisonderskeiding. Die verskillende betekenisonderskeidinge hou met mekaar verband deur betekeniskettings. Skematies uitgedruk: betekenisonderskeiding $A$ hou verband met betekenisonderskeiding $B$ op grond van een of meer gedeelde attribute of een of ander ooreenkoms. Betekenisonderskeiding $B$ dien weer as bron vir ' $n$ verdere betekenisuitbreiding $C$, wat op dieselfde wyse met betekenisonderskeidinge D en E verband hou, ens. Hierdie proses kan soos volg voorgestel word:

$$
\mathrm{A} \rightarrow \mathrm{B} \rightarrow \mathrm{C} \rightarrow \mathrm{D} \rightarrow \mathrm{E}
$$

Binne die kategorie bestaan die betekenisrelasies in die eerste plek tussen die aangrensende lede, terwyl lede wat nie aangrensend is nie, in feite min met mekaar gemeen kan hê, maar wel aan mekaar verwant is via die tussenliggende betekenisskakels. In beginsel kan enige knoop in so ' $n$ ketting die bron wees van enige aantal betekenisuitbreidings sodat PTKe multidimensionele betekeniskonstrukte kan vorm.

Volgens Lakoff (1987: 84) is 'n PTK in hierdie opsig tipies 'n "radial category" ("speekkategorie"), wat hy soos volg omskryf:

A radial structure is one where there is a central case and conventionalized variations on it which cannot be predicted by general rules.

en

The radial structuring of categories involves the following:

- A conventional choice of center.

- Extension principles. These characterize the class of possible "links" between more central and less central subcategories. They include metaphoric models, metonymic models, imageschema-relations, etc.

Lakoff (1987: 95-96) beskou kettingvorming ("chaining") juis as een van die sentrale kenmerke van menslike kategorisering. Laasgenoemde omskryf hy soos volg:

Chaining: Complex categories are structured by chaining; central members are lin ked to other members, which are linked to other members, and so on. 
Specific conventional extensions. Though each extension is an instance of the extension principles, the extensions are not predictable from the center plus the principles. Each extension is a matter of convention and must be learned. The fact that specific extensions are instances of general principles makes them easier to learn. (Lakoff 1987: 204)

Gegee dat elke betekenisonderskeiding self weer as die basis vir verdere ontwikkelinge kan dien, vertoon polisemiese kategorieë intern 'n komplekse netwerkstruktuur waarin die onderskeie betekenisonderskeidinge, -nuanses en -toepassinge rondom bepaalde kerne gegroepeer is, en gegee dat elke betekenisonderskeiding weer self as uitgangspunt vir verdere betekenisontwikkeling kan dien, verskeie sulke kleiner, maar verbonde netwerke, waarin die lede van elke subnetwerk en lede oor die grense van subnetwerke heen inhoudelik met mekaar kan oorvleuel.

Nog twee opmerkinge oor die voorafgaande. Die eerste is dat hierdie strukturele konsepsie korreleer met die diachroniese en sinchroniese feit dat nuwe betekenisonderskeidinge of -nuanses uit ander bestaande betekenisonderskeidinge ontwikkel en dat dié weer as basis vir verdere betekenisontwikkeling kan dien. Die resultaat is dat enige betekenisonderskeidinge en die ontwikkelinge daaruit 'n speekstruktuur vertoon met 'n sentrale betekenisonderskeiding en daaruit afgeleide betekenisonderskeidinge.

Histories gesien kom so 'n leksikale speekstruktuur in die loop van die tyd tot stand; sinchronies karakteriseer dit die interne struktuur van 'n PTK. Anders gestel: sinchroniese strukturele kompleksiteit is die sinchroniese kant van die diachroniese proses van leksikale strukturering. Gegee hierdie feit word die Saussuriaanse digotomie van diachronie versus sinchronie in taalkundige teoretisering en beskrywing in KS opgehef: die dinamiese beginsels van taalverandering wat die strukturalisme net diachronies kan benader, maar wat aan die basis van die totstandkoming van interne leksikale kompleksiteit lê, word ingelyf by die sinchronies plooibare aard van leksikale konsepte.

Hierdie opheffing steun wesentlik op die insig dat die (diachroniese) meganismes van taalverandering enersyds die sinchronjese semantiese relasies tussen die gekonvensionaliseerde betekenisonderskeidinge van polisemiese leksikale items beheers, maar andersyds ook die aard en grense van sinchroniese taalverandering in taalgebruikskontekste stipuleer (vgl. Geeraerts 1985b; Bartsch 1987), d.i. kensketsend is van ('n deel van) die leksikale kreatiwiteit van die taalgebruiker. Laasgenoemde setel daarin dat die taalgebruiker enersyds oor die vermoë beskik om nuwe betekenistoepassinge van 'n woord in konteks te inisieer en setel andersyds in die vermoë om sulke nuwe toepassinge in konteks te interpreteer. Wat dus vanuit een gesigspunt as diachroniese verande- 
ring gesien word, is met ander woorde bloot die realisering van sinchronies be skikbare moontlikhede vanuit ' $n$ ander gesigspunt. ${ }^{23}$

Dat dit in die leksikografiese ondersoek na die intraleksikale semantiese strukturering van leksikale kategorieë nie altyd wenslik is om 'n rigiede onderskeid of afgrensing van die diachroniese en die sinchroniese benadering tot die gegewens te handhaaf nie, is 'n sentiment wat ook Zgusta deel as hy sê dat "some unobtrusive historicism (if possible) is not out of place" (vgl. Zgusta 1971: 277, voetnoot 3).

Die tweede belangrike feit is dat die familieverwantskap tussen betekenisonderskeidinge nie net tot 'n enkele kategorie beperk is nie, maar oor kategoriegrense (gegee vormlike identiteit en semantiese verwantskap) kan strek. In die meeste KG-analises word daar dus sowel op gevalle van intrakategoriale grammaties-semantiese variasie (bv. die onoorganklike en oorganklike gebruik van dieselfde woordvorm) en gevalle van heterosemie (funksiewisseling met behoud van woordvormlike identiteit of interkategoriale variasie) (vgl. Persson 1988 en Lehrer 1989) gelet. Wat dus van kardinale belang blyk te wees, is nie soseer die verskil in grammatiese funksie tussen leksikale items nie, maar wel of daar sprake van (sistematiese) semantiese verwantskappe is al dan nie tussen vormlik identiese leksikale items. ${ }^{24}$

Leksikografies gesien het die voorafgaande direk betrekking op die makrostrukturele ordening/groepering van lemmas in verskillende of dieselfde woordeboekartikels.. Word die alfabetiese rangskikkingsmetode aanvaar, dan moet die leksikograaf verder besluit oor hoe hy vormlik identiese leksikale items gaan hanteer, d.w.s aan watter hy afsonderlike woordeboekartikels gaan

23 As sodanig is hierdie meganismes van leksikale ontwikkeling interpreteerbaar as interpretatiewe beginsels, d.i. strategieë om kontekstueel funksionele toepassings/gebruike van konsepte in terme van ons bestaande leksikale kennis te interpreteer (vgl. Geeraerts 1989b: 655-656, 659-662, en ook Bartsch 1987: 218-226 en Cruse 1986: 71-80).

Omgekeerd bied die insigte oor die aard van sinchroniese leksikale beheersing en kreatiwiteit weer ' $n$ basis vir die ondersoek na die prosesse en meganismes van taalverandering (vg. Geeraerts 1985b; Traugott 1985, 1986 en Sweetser 1990).

24 Die relasie van heterosemie geld bv. tussen die werkwoord drive (die superordinaat) en die volgende naam woordelike kohiponimiese afleidings drive ( $N$, Instance or act of $V$ ); drive (N, Means); drive (N, Location). Persson (1988: 277) onderskei ten opsigte van die relasie van heterosemie ook tussen transkategoriale heterosemie (bv. hussen drive ( $W w$ ) en die drie naamwoordelike afleidings) en gevalle van subkategoriale heterosemie, d.i. die relasie tussen betekenisonderskeidings wat binne dieselfde woordsoortkategorie deur funksiewisseling ontstaan, bv. tussen stand (onoorganklike werkwoord) en stand (oorganklike, kousatiewe werkwoord). Vir Ig. gebruik hy die term synsemy wat wesentlik 'n vertikale relasie (of kategorie-inteme relasie) van verwantskap is tussen ' $n$ fonologies identiese superordinaat en in subkategoriale hiponiem. Hierteenoor is heterosemie ' $n$ horisontale betekenisrelasie tussen fonologies-identiese kohiponieme van in gemeenskaplike superordinaat (vgl. Persson 1988: 278). 
wy en watter gevalle hy binne 'n enkele woordeboekartikel gaan beskryf. Verskillende moontlikhede doen hulle in hierdie verband voor, maar daar bestaan in alfabeties gestruktureerde, verklarende woordeboeke 'n aantal algemene tradisionele opsies.

Die eerste is dat homonimiese leksikale items in aparte woordeboekinskrywings hanteer word. Struktureel sou hierdie ordeningsmetode die linguistiese aanname kon beliggaam dat vormlik-identiese lemmas wat in verskillende woordeboekartikels beskryf word, inderdaad nie semanties met mekaar verband hou nie, maar verteenwoordigend is van verskillende leksikale items. 25

In die gevalle van funksiewisseling word hoofsaaklik een van twee metodes gevolg: na gelang van die onderskeie woordsoorte waartoe die vormlik identiese leksikale item behoort, word 'n aparte woordeboekinskrywing aan elke woordsoortkategorie gewy (soos in die geval van homonimie), of die verskillende woordsoortlike gebruike word onder 'n enkele woordeboekinskrywing hanteer.

Die vraag is nou of die keuse van enige van hierdie metodes enige teoreties-linguistiese implikasies/korrelasies het. Vanuit die perspektief van semantiese verwantskap sou dit ' $n$ voor die hand liggende keuse wees om gevalle van interkategoriale verwantskap binne die domein van 'n enkele woordeboekinskrywing te hanteer. Struktureel word daarmee dan gesinjaleer dat gevalle van nie-semantiese verwantskap (homonimie) struktureel onderskei word van dié van semantiese verwantskap oor woordsoortkategorieë heen.

'n Gewoon pragmaties-funksionele oorweging wat egter hier 'n rol (kan) speel, is die keuse van 'n aanbiedingswyse wat dit vir die gebruiker moontlik maak om inligting in ' $n$ woordeboek doeltreffend na te kan slaan, in welke geval die aanbieding van gevalle van homonimie en interkategoriale verwantskap op 'n gelyke voet geplaas word, d.i. 'n homoniem en die gevalle van funksiewisseling word dan elkeen in aparte woordeboekinskrywings hanteer met 'n duidelike stelsel van numerering om die afsonderlike lemmas te merk. Hierdie werkwyse het die voordeel dat die gebruiker nie deur al die inligting in 'n woordeboekartikel hoef te waad om die relevante inligting te soek nie. Met hierdie werkwyse word dit dan aan die woordeboekgebruiker oorgelaat om, indien hy inderdaad in die aspekte van semantiese verwantskap tussen vorm-

In die woordeboekpraktyk kom dit egter ook voor dat woordeboeke wat inderdaad hierdie beginsel aanvaar en woordeboekinskrywings dienooreenkomstig inrig betekenisonderskeidings onder ' $n$ bepaalde lemma opneem waarvan die semantiese verwantskap met die ander betekenisonderskeidings onder die enkel lemma nie duidelik is nie. Die vraag is dan of hierdie nie-verwante betekenisonderskeiding as ' $n$ geval van homonimie beskou moet word of nie. Talle voorbeelde hiervan kom in HAT voor. ' $n$ Eenvoudige antwoord hierop is nie moontlik nie aangesien mens eers duidelikheid moet kry oor watter interpretasie van "betekenisverwantskap" hier ter sake is, di. of die insluiting van so "n betekenisonderskeiding op histories-etmologiese gronde of op sinchroniese verwantskap berus. 
lik identiese leksikale items belangstel, dit self na te gaan - ' $n$ taak wat vergemaklik word deur die feit dat die onderskeie woordeboekinskrywings alfabeties byeengeplaas is.

\subsubsection{Sentrale en periferale lede}

Die derde kenmerk hier bo ondervang die feit dat nie alle lede/betekenisonderskeidinge, -nuanses of -toepassinge van 'n PTK gelyke status het nie. Die asimmetrie in strukturele gewig is egter nie net beperk tot die verhouding tussen betekenisonderskeidinge of -waardes onderling nie; dit geld ook ten opsigte van die betekeniskomponente van individuele betekenisonderskeidinge.

Die organisasie van die betekenisonderskeidinge binne ' $n$ woordeboekartikel is een van die kernprobleme waarmee die leksikograaf ook te make het (vgl. Zgusta 1971: 275 e.v.), en soos hier onder sal blyk, word daar rondom die meerduidige interpretasie van die begrip "prototipe" of "sentrale lid" van 'n kategorie ' $n$ hele aantal moontlikhede geopen m.b.t. die interne struktuur van polisemiese kategorieë, maar dan perspektiewe wat nie self vreemd aan die metaleksikografie is nie.

Die prominentste lid van 'n PTK staan bekend as die prototipe van die kategorie. Hierdie term word in die KS-literatuur egter meerduidig gebruik. In die geval van ekstensionele prototipisiteit verwys dié term na die sentrale lid/mees verteenwoordigende lid van die kategorie; ten opsigte van die kategorie voël sou 'n lid soos mossie bv. in hierdie sin as die prototipe van die kategorie beskou kon word. In die geval van intensionele prototipisiteit sou die prototipe in ooreenstemming hiermee die betekenisonderskeiding moes wees wat intuitief as die dominante/primêre betekenisonderskeiding, soos tradisioneel ook in die leksikografie gedefinieer, beskou kon word. Ter illustrasie: kat het onder meer die volgende betekenisonderskeidinge: "klein, viervoetige huisdier wat muise vang" en "wilde dier van die kattegeslag". Buite linguistiese konteks is eg. betekenisonderskeiding die dominante een en in dié sin die mees "verteenwoordigende" een vir die kategorie as geheel. So geïnterpreteer het die term prototipe en die leksikografiese term dominante/primêre betekenisonderskeiding dieselfde denotasie. Die term dominante betekenisonderskeiding is egter 'n psigologistiese een: "In psychologistic terms, the dominant sense is the one which is the first to be thought of by the majority of the speakers of a language if presented with the word in isolation, without any context" (Zgusta 1971: 64).

Soos Taylor (1989: 118) egter aantoon, word lidmaatskap in 'n speekkategorie nie beslis op grond van ooreenkoms met die sentrale lid nie, maar op grond van die kettingproses. Dus het die sentrale lid van 'n speekkategorie nie dieselfde psigologiese status as die prototiperepresentasie van 'n monosemiese kategorie soos VOëL nie. Hierbenewens kan die periferale lede van 'n speekkategorie nie vergelyk word met die periferale lede van 'n prototipekategorie nie. 
Volgens Geeraerts is dit egter 'n uitvloeisel van die familieverwantskapstruktuur van PTKe dat 'n lid wat die meeste kenmerke met ander lede deel, die strukturele oorwig in ' $n$ PTK het. In hierdie opsig is die prototipe van die kategorie die besondere lid/betekenisonderskeiding wat die meeste kenmerke met lede gemeen het. Die sentrale lid is dan die betekenisonderskeiding wat geëkspliseer moet word in terme van al die kenmerke wat lede van die kategorie deel en waarvan die nie-sentrale lede dan net een attribuut of enkele attribute met die sentrale lid deel. (Vgl. Geeraerts 1987b: 282-283.)26 Hierdie verskynsel kan soos volg geillustreer word:27 die eerste betekenisonderskeiding van vars soos wat dit met verwysing na verskillende voedselsoorte gebruik word, het as betekenis "resent geproduseer, en as sodanig optimaal vir gebruik" (vgl. vars brood, vrugte, groente, ens.). Hierdie betekenisonderskeiding kan as die konjunksie van twee kenmerke ontleed word, nl. die begrip "resent, nuut, nie oud nie" en "optimaal, in 'n optimale kondisie". Hierdie twee betekeniskomponente kan egter apart geaktiveer word, bv. in 'n vars wond is die begrip "optimaal" nie aanwesig nie, terwyl "ongekontamineerd" in plaas van "resent geproduseer" die geaktiveerde komponent is in 'n uitdrukking soos vars lug. Hierdie twee kenmerke kombineer egter in die eerste betekenisonderskeiding waar vars van toepassing is op vrugte, brood, ens. Die sentrale lid van die kategorie is in hierdie geval dus daardie betekenisonderskeiding waarin die relevante betekeniskenmerke maksimaal oorvleuel of gelyktydig geaktiveer word.

Strukturele oorwig sou egter ook kon impliseer dat die sentrale of dominante lid as basis vir die afleiding van ander betekenisonderskeidinge, -nuanses of -toepassinge dien. In hierdie sin word die sentrale betekenisonderskeiding/lid (of dan die prototipe) verstaan as die betekenisonderskeiding wat as basis vir die afleiding van ander betekenisonderskeidinge, -nuanses en toepassinge (ge)dien (het). ${ }^{2 B}$ So gesien, is die sentrale lid dan daardie betekenisonderskeiding waarmee die ander (sinchronies) op die mees geloof waardige en ekonomiese wyse in verband gebring kan word.

26 Dit is ook Lakoff (1987: 416-461) se uitgangspunt in sy ontleding van die setsel over. Die niesentrale betekenisonderskeidings is die wat in een of meer attribute van die sentrale lid afwyk.

Die voorbeeld is hier aangepas n.a.v. ' $n$ voorbeeld van die betekeniswaardes van vers in Nederlands (vgl. Geeraerts 1987b: 282-283).

Die identifisering van die sentrale lid van 'n PTK is volgens Taylor (vgl. Taylor 1989: 116-121) problematies as die lid wat intuïtief as die sentraalste lid aangevoel word, nie ooreenstem met die basisvlakbetekenisonderskeiding in 'n kategorie nie. Basisvlakterme maksimaliseer die informatiwiteit van 'n kategorie: alhoewel kategorieë op hulle grense ineen kan vloei, is die prototipiese lede van basisvlakkategorieë maksimaal verskillend. In die geval van twee nabysinonieme is die sentrale betekenisonderskeidinge daarvan egter nie maksimaal verskillend nie, d.w.s. hulle maksimaliseer nie katgorieonderskeiding nie. 
In hierdie opsig korreleer die interpretasie van die term prototipe met wat Zgusta as die direkte betekenisonderskeiding van 'n kategorie aandui:

the direct sense is the sense from which other senses can, in the semantic analysis, be derived by the assumption that they are characterized by some added connotation, or by the sense being figurative, or in a similar way: they are marked, whereas the direct sense is unmarked. Direct senses will usually be those which do not belong to a special restricted language, style etc. (Zgusta 1971: 61-62)

Die interpretasie van die direkte betekenisonderskeiding as die een waarvan ander afgelei kan word, is egter meerduidig. Eerstens kan dit histories geinterpreteer word as " basic sense = the most original one, from which all the other senses really developed" (vgl. Zgusta 1971: 65-66); tweedens, kan dit logies (en miskien sinchronies-analities meer relevant) geinterpreteer word as of "the sense from which the other senses can be derived" of as "a general sense that covers the single senses" (vgl. Zgusta 1971:66).

Uit die voorafgaande moet dit duidelik blyk dat daar geen eenstemmigheid oor ' $n$ enkele interpretasie van die term prototipe in terme van PTKe bestaan nie. Elke interpretasie open egter 'n alternatiewe perspektief op die interne strukturering van 'n kategorie, en as sodanig ook 'n stel relevante alternatiewe wat in die leksikografie by die interne strukturering van die betekenisonderskeidinge van 'n polisemiese leksikale item 'n rol sou kon speel.

Die historiese interpretasie van die begrip "prototipe" sal baie duidelik in die geval van die eentalig-verklarende historiese woordeboek as ordeningspunt dien. Zgusta (1971: 65-66) aanvaar dat die leksikograaf in die geval van die sinchroniese woordeboek hom in die ordening/strukturering van die betekenisonderskeidinge egter moet laat lei deur die psigologistiese begrip ván die dominante betekenisonderskeiding.

Vir die sinchroniese woordeboek is die probleem met die historiese interpretasie van basiese betekenisonderskeiding dat die historiese feite met die sinchroniese in botsing kan wees. Die historiese feite kan volgens Zgusta egter wel benut word indien daar geen ander faktore is wat vir 'n sinvolle ordening ingespan kan word nie.

Vanuit die perspektief van die sinchroniese woordeboek is die probleem met die logiese interpretasie van die begrip "basiese betekenisonderskeiding" dat verskillende betekeniswaardes as basis vir die afleiding van die ander betekeniswaardes geneem sou kon word, en ten opsigte van die tweede interpretasie is die probleem dat daar dikwels nie so "n oorkoepelende betekenisonderskeiding in die data sal wees nie:

The logical interpretation of the term basic sense also causes some difficulties. Is it the sense from which the other senses can be derived, by a logical procedure, which should be regarded as the basic one? If 
so, it will be impossible to find it, in the majority of cases, or there will be several candidates to the title. Or is it a general sense that covers the single senses which should be regarded as the basic one? But there will most often be no such sense observable in the linguistic data. (Zgusta 1971:66)

Zgusta (1971: 65) noem in hierdie verband nog 'n ander probleem, nl. dat sommige woorde meer as een direkte betekenisonderskeiding het waarvan nie een duidelik as die dominante betekenisonderskeiding beskou kan word nie. Hierdie probleem kom veral voor as al die betekeniswaardes ewe min of ewe veel (vgl. byvoorbeeld werk) gebruik word.

Zgusta (1971: 66) kies in die geval van die sinchroniese woordeboek daarom die psigologistiese uitgangspunt vir die leksikografie:

The psychologistic approach with the notion of the dominant sense has at least the advantage that it brings results observably based upon the way in which speakers themselves understand their own language - a factor certainly not irrelevant or foreign to the linguistic world.

Ten spyte van hierdie probleme word daar in ooreenstemming met die verskillende uitgangspunte hier bo in die leksikografie dan ook verskillende ordeningsmetodes voorgestaan, maar spesifieke keuses word op grond van teoretiese en pragmaties-funksionele oorweginge soos die beoogde gebruiker en gebruike van die woordeboek gemaak.

Die belangrikste metodes is die volgende:

(i) die historiese ordening, wat deur groter omvattende woordeboeke soos die WNT gevolg word, maar dan ook soos bepaal deur die beskikbaarheid van die historiese data. Meestal word die historiese benadering aangevul met die logiese of epistemologiese stelsel waar semantiese verwantskap en die konsep van 'n dominante betekenisonderskeiding die deurslag sal gee. Dié gebeur veral waar die historiese data nie duidelike uitsprake maak nie;

(ii) die logiese ordening, waarin die dominante betekenisonderskeiding en die semantiese verwantskap van betekeniswaardes die deurslag gee. Dit het egter nie 'n onfeilbare metode tot gevolg nie omdat die toepassing van hierdie kriteria nie altyd eenduidige resultate oplewer nie. Zgusta (1971: 276 e.v.) verskaf gevolglik die onderstaande riglyne:

(a) Indien in dominante betekenisonderskeiding geïsoleer kan word, word dié eerste geplaas. 
(b) Ontbreek ' $n$ dominante betekenisonderskeiding moet die betekeniswaarde wat die breedste toepassing en geen gemerkte konnotasies het nie, eerste geplaas word. Alle ander meer gespesialiseerde, spesifieke of tegniese betekenisonderskeidings van die beperkte registers en style kom dan daarna, en wel in 'n volgorde "which seems optimal to the lexicographer: it is such an order in which those senses which follow each other usually differ from each other by fewer semantic features or by less important ones than those which are situated further apart in the sequence" (Zgusta 1971: 277).

(c) Indien meer as een dominante betekenisonderskeiding (of breë, algemene betekenisonderskeiding) geïsoleer kan word, moet hierdie dominante betekenisonderskeidings nie almal aan die begin geplaas en die periferale betekenisonderskeidings van elk daama nie. Die mees effektiewe metode is om elke dominante betekenisonderskeiding te laat volg deur die meer gespesialiseerde, spesifieke en tegniese betekeniswaardes wat semanties daarmee verband hou.

(d) ' $n$ Meer periferale geval is dié waar nie een van die betekeniswaardes van 'n leksikale item 'n goeie keuse as eerste kandidaat is nie (vgl. Zgusta 1971: 276, voetnoot 175). Zgusta gee dan as riglyn dat die verskillende betekenisonderskeidinge in klosters van die nouste verwante betekenisonderskeidinge groepeer moet word of in opeenvolging gegee moet word.

Zgusta aanvaar ten opsigte van die keuse van 'n spesifieke ordening dan ook dat die sinchroniese en die diachroniese perspektief nie streng geskei behoort te/kan word nie (vgl. Zgusta 1971: 276, voetnoot 175; 278, voetnoot 179).

Aangesien ' $n$ PTK meer as een betekenisonderskeiding het en allerlei betekenistoepassinge en -nuanses rondom elkeen hiervan kon ontwikkel het of nog kan ontwikkel, kan enige PTK bestaan uit ' $n$ versameling sodanige betekenisklosters. Alhoewel Geeraerts nie hierop in besonderhede ingaan nie, sou mens kan aanvaar dat elke betekeniskloster 'n prototipe het, en dat een daarvan dan heel waarskynlik as prototipe vir die kategorie as geheel sou kon optree sodat die betekenisklosters as sodanig ook deur bepaalde verwantskapsrelasies met mekaar verbind sou kon wees.

Laasgenoemde siening is egter problematies in die lig van die definisie van die prototipe van 'n PTK as die lid wat die maksimale aantal attribute met die ander lede van die kategorie deel. Alhoewel hierdie interpretasie vir PTKe met 'n redelik eenvoudige struktuur kon geld, kan dit egter in PTKe met 'n meer komplekse struktuur gebeur dat nie een van die lede die attribuutkorrelasie binne die kategorie maksimaliseer nie.

Dat die keuse van die prototipe van ' $n$ PTK vanuit meer as een sodanige perspektief benader en vanuit verskillende faktore bepaal kan word, word verder onderstreep deur die soort riglyne wat mens uit Geeraerts (1985a: 215-219) kan abstraheer. Twee soorte gegewens word hier in die bepaling van 
die status van betekenisonderskeidings in aanmerking geneem, nl. gegewens gebaseer op die taalgebruiksdata en dié wat op introspeksie berus. Ten opsigte van eersgenoemde is die volgende van belang:

die betekenisonderskeiding wat die frekwentste in die taalgebruiksdata na vore kom (bv. die konkrete of abstrakte betekenisonderskeiding, -toepassing). Hier gaan dit spesifiek oor linguistiese frekwensies en nie om referensiële frekwensies nie;

die produktiwiteit van die onderskeie betekeniskerne, d.i. die aantal en aard van die betekenisverbreidings van elke kern (sentrale of prototipiese lede vertoon meer toepassings en nuanses, wat by periferale lede ontbreek). As onderdeel van die produktiwiteit van 'n kern kan daar ook gelet word op verskille ten opsigte van die aantal en soort (bv. metonimiese en metaforiese verbredings) van die onderskeie kerne; of die onderlinge verhouding tussen die abstrakte en konkrete verbreidings by spesifieke betekenistoepassinge en -nuanses van elke kern;

(iii) die soort betekenisonderskeiding wat in produktiewe morfologiese afleidings figureer;

(iv) die betekenisonderskeiding wat etimologies die prominentste figureer.

Onder die introspektiewe data val oordele van moedertaalsprekers oor die dominante betekenisonderskeiding(e) van 'n leksikale item. In die praktyk is dit meestal so dat moedertaalsprekers se oordele oor die betekenisonderskeidinge van ' $n$ leksikale item nie in 'n een-tot-eenverhouding staan tot die feite van taalgebruik nie. Die wyse waarop dié oordele egter ter sake is, verduidelik Geeraerts (1985b: 218) soos volg:

... given the presupposition that introspection yields only a partial insight into the semantic structure of words that are investigated, we can also presuppose that it will be exactly the prototypical kinds of usage of those words, that reach the introspective consciousness of the language user. We can use the results of the introspective method as support for the prototypical hypothesis if we presuppose that prototypical kinds of usage (precisely because they are more salient than other applications) will more easily pass the threshold of conscious attention. Given this presupposition, the introspective judgements of native speakers may shed light on the question which kinds of usage are predominant within a certain concept.

Alhoewel dus nie vreemd aan die leksikografieteorie en -praktyk nie, toon die voorafgaande dat die probleem van die strukturele gewig in ' $n$ kategorie, self vanuit verskillende perspektiewe benader kan word. Ten spyte van die voor- 
keur wat Zgusta (1971) self aan die psigologistiese uitgangspunt gee, beklemtoon ook hy dat in sinchroniese woordeboeke dikwels meer as een uitgangspunt in die interne strukturering van woordeboekartikels gevolg word. Bostaande poog dan ook net om hierdie alternatiewe op 'n ry te plaas; verdere ondersoek na die implementering daarvan in die woordeboekpraktyk is in hierdie opsig nog nodig.

\subsubsection{Die vaagheid van grense}

Die vierde kenmerk het te make met die grense van polisemiese kategorieë. Teenoor die klassieke beskouing dat kategorieë logies gebonde entiteite is, word daar in die prototipeteorie aanvaar dat polisemiese kategorieë vae grense het. Hierdie feit volg logieserwys uit die vorige kenmerk omdat die onderskeid tussen prototipiese kerne met periferale sones impliseer dat die periferale betekenisonderskeidinge, wat die grense van kategorieë definieer, self met die betekenisonderskeidinge van aangrensende leksikale kategorieë kan oorvleuel. Andersins word die nie-rigiditeit van polisemiese kategorieë gemanifesteer in die feit (i) dat daar nie 'n enkele oorkoepelende of afdoende en noodsaaklike definisie verskaf kan word wat al die betekenisonderskeidinge, -toepassinge en -nuanses van 'n polisemiese kategorie ondervang nie, en (ii) dat betekenisonderskeidinge, toepassings en -nuanses inhoudelik oorvleuel (vgl. Geeraerts 1988c: 345-346).

Zgusta self (vgl. Zgusta 1971: 47) interpreteer die interne en die eksterne vaagheid van kategoriegrense as 'n funksie van die algemeenheid/breë toepassingsmoontlikhede wat eie aan alle leksikale items is:

the designata are usually broad (cf. how many different things can be referred to as furniture), frequently overlapping (cf. that it is possible to refer to the same quality of a great number of things both with the adjective big and large), and sometimes lacking clear boundaries (i.e., are not sufficiently criterial; cf. honesty, justice, etc.)

\subsubsection{Monosemiese PTKe vs. polisemiese PTKe}

'n Monosemiese leksikale item word met ' $n$ enkele betekenisonderskeiding geassosieer, terwyl polisemie die assosiasie is van twee of meer verwante betekenisonderskeidings met dieselfde linguistiese vorm. Een van die kernprobleme in PT is die vraag of alle kategorieë wat die aangeduide kenmerke van PTKe vertoon, inderdaad polisemies is.

Geeraerts (1987b: 278) wys in hierdie verband daarop dat daar twee aspekte of perspektiewe is van waaruit 'n leksikale item as semanties monosemies (eenduidig) of as polisemies (meerduidig) beskou kan word; die eerste is vanuit ' $n$ analitiese perspektief, die tweede is vanuit die moedertaalsprekers se 
intuitiewe oordele oor monosemie of polisemie. Hierdie twee aspekte moet uiteengehou word omdat die twee perspektiewe, soos die verskillende perspektiewe op strukturele gewig in 'n kategorie, uiteenlopende resultate kan oplewer.

Ter illustrasie kan ons kyk na Geeraerts se ontleding van die betekenis van die leksikale item voël (bird). Die ekstensie van hierdie woord sluit ook mossies, pikkewyne, volstruise en ander voëlsoorte in. Vir sover mossies as die sentrale lid/prototipe van die kategorie beoordeel word, voldoen dit aan dié kenmerk dat die kategorie as 'n PTK gestruktureer is. ' $n$ Verdere eienskap wat dit vertoon, is dat die ekstensionele bereik van die kategorie nie in 'n enkele oorkoepelende definisie ondervang kan word nie. Neem mens bv. NWB se definisie van voël as "dier met vere en vlerke", dan geld dit wel dat voëltjies soos die mossie, vink, ens. byvoorbeeld almal aan hierdie kenmerke voldoen, maar mens sou nie van pikkewyne kon sê dat hulle vere het nie. 'n Verdere onderskeid tussen lede van die kategorie is bv. dat mossies en ander klein voëltjies kan vlieg, maar volstruise nie. Wat wel uit die definisie blyk, is dat daarin slegs die kenmerke van die sentrale lid van die kategorie opgeneem word, d.i. van die mees verteenwoordigende lid van die kategorie. As sodanig is die definisie nie breed genoeg om die volle ekstensie van die woord te ondervang nie.

Die probleem is egter dat die kategorie voël, ten spyte van die ekstensionele prototipisiteit daarvan, intuitief intensioneel as 'n monosemiese kategorie ervaar word sodat geen familieverwantskapstruktuur daarvoor op die intensionele vlak geponeer kan word nie (gegee dat mens hier net op die letterlike betekenisonderskeiding van die kategorie let en nie op die figuurlike betekenisonderskeidinge daarvan nie). Die konsep VOëL het baie duidelik nie vae grense nie. Sprekers kan voëls van nie-voëls onderskei, maar hulle weet ook dat ' $n$ mossie meer verteenwoordigend van die kategorie is as wat ' $n$ volstruis is. ${ }^{29}$

Hierteenoor is 'n leksikale items soos vars én analities én intuitief prototipies. NWB onderskei bv. die volgende betekeniswaardes vir hierdie item:

1. pas geslag, gebak, gepluk (brood, vleis, vrugte).

2. nie sout(erig) nie (vleis).

3. kort vantevore ontstaan, gebeur (spore).

4. uitgerus (perde).

5. nuut, wat ' $n$ ander vervang (pleister). maatskap in hierdie kategorie is diskreet (d.w.s. nie gegradeerd nie), maar verteenwoordiging van die kategorie is nie, aangesien sommige lede van die kategorie "meer voël" is as ander. 
Die uiteenlopendheid van die betekenisonderskeidinge maak dit onmoontlik om 'n maksimaal algemene en gelyktydig minimaal spesifieke definisie uit hierdie betekeniswaardes vir die kategorie as 'n geheel te abstraheer. Intuitief en intensioneel verteenwoordig vars 'n polisemiese kategorie, soos geillustreer deur die meerledige betekeniswaardes van die leksikale item. Die implikasie is dus dat waar die periferale lede van voël intuïtief nie as semanties apart ervaar word nie, dit wel die geval is met vars.

Geeraerts (1988c, 1989b) se hoofbetoog is dus dat hierdie vier kenmerke van prototipisiteit nie noodwendig al vier teenwoordig is in die geval van kategorieë wat prototipisiteit vertoon nie en dat die eerste kenmerk alleen (of elkeen apart) nie afdoende is om polisemiese PTKe van monosemiese PTKe te onderskei nie.

Monosemiese PTKe deel dan juis hierdie kenmerk dat hulle semanties as vaag beskou word, en polisemiese PTKe dat hulle werklike gevalle van meerduidigheid vertoon. Wat semanties-teoreties en leksikografies dus van belang blyk te wees, is dat die ontleder/leksikograaf vir hom vooraf duidelikheid moet kry (i) oor wat met "betekenis" en "meer as een (verwante) betekenis" binne die konteks van die onderskeid tussen polisemie en monosemie bedoel word, en (ii) vanuit watter perspektief, d.i. analities of intuitief, daar van een of meer betekenisse sprake is.

Die probleem ten opsigte van wat met "meer as een betekenis" in hierdie verband bedoel word, gaan in die eerste plek daarop terug dat taalgebruik-inkonteks as vertrekpunt vir die ontleding van leksikale betekenis dien ${ }^{30}$ en dat betekenisvariasie in konteks as kriterium vir die ontleder en die gewone taalgebruiker as basis dien van besluite oor die feit of 'n leksikale item meer as een betekenis het of nie. ${ }^{31}$

30 Een van die sentrale uitgangspunte van $K G$ waarin dit in die besonder by die leksikografiese werkwyse aansluit, is dat leksikale betekenis empiries as gebruiksbetekenis benader word, d.i. vanuit die volledige konseptualisering daarvan in taalgebruikskontekste. Benewens die betekenisonderskeidinge van in leksikale item, word daar dus ook aan die nie-gestabiliseerde en minder gestabiliseerde betekenisnuanses en -toepassinge van 'n leksikale item aandag gegee soos wat dit in taalgebruikskontekste na vore kom. Gebruiksbetekenisse vorm die beginpunt van die ontleding en klassifisering van die betekeniswaardes van leksikale items. Vanuit kontekstuele gebruik moet 'n ontleder bepaal of die afsonderlike gebruiksbetekenisse nuwe betekeniswaardes/-onderskeidinge van 'n leksikale item is, identiese instansiërings of uitbreidings op die gekonvensionaliseerde betekenisonderskeiding van in leksikale item.

31 Die besondere aandag in KS vir taalgebruiksbetekeniswaardes volg verder uit die feit dat dit slegs vanuit hierdie waardes moontlik is om die proses van semantiese verandering te rekonstrueer, om die subtiele oorgange en oorvleueling in betekeniswaardes van 'n leksikale item te ondervang en om die sinchroniese verwantskappe en van verskille tussen betekeniswaardes rekenskap te kan gee. Soos'Lakoff (1987: 418) aantoon, vorm taalgebruiksbetekeniswaardes onder meer die sentrale uitgangspunt omdat taalgebruiksgevalle self nie 
Vanuit die teoreties analitiese perspektief is die probleem dat mens met die gebruik van leksikale items in konteks met leksikale konseptualiseringe/betekeniswaardes van ongelyke status te make het, waar die variasie in status langs kontinue parameters soos semantiese onderskeidendheid en gestabiliseerdheid/gekonvensionaliseerdheid kan varieer. Alle leksikale konseptualiseringe in konteks word egter nie vanuit analitiese perspektief as van wesentlike belang beskou nie.

Geeraerts vertrek in hierdie verband vanuit 'n baie breë opvatting van die begrip "sense". Daaronder val vir hom "any type of linguistic phenomena that is semantically distinct" (Geeraerts 1983b: 4, voetnoot 9). Alhoewel enige semantiese teorie sowel van leksikale konseptualiseringe as van leksikale betekenisonderskeidinge rekenskap kan gee, aanvaar Geeraerts dat slegs betekenisonderskeidende waardes ter sake is by die bepaling van die polisemiese of prototipiese status van 'n kategorie (vgl. Geeraerts 1987b: 276-277).

Vanuit analitiese oogpunt word hierdie probleem vanuit sowel die ekstensionele of die referensiële aspekte van 'n kategorie as vanuit die intensionele aspek daarvan beskou (vgl. Geeraerts 1989a: 49). In hierdie opsig word aanvaar dat nie alle referensiële betekenisverskille met semanties onderskeidende verskille ooreenstem nie. In besluite hieroor laat die semantikus (en die leksikograaf) hom lei deur die teoretiese onderskeid wat daar tussen vaagheid en meerduidigheid getref word.

Die term vaagheid verwys in hierdie verband na die verskynsel dat die betekenis van 'n woord ongespesifiseerd kan wees ten opsigte van sekere toepassinge/ekstensies daarvan, d.w.s nie as wesentlike deel van die betekenis daarvan 'n onderskeid maak tussen sekere waardes daarvan nie. Vergelyk bv. die feit dat 'n uitdrukking soos 'n rooi boek gebruik kan word om te verwys na boeke wat allerlei skakeringe van die kleur rooi kan vertoon. Hierdie verskille is irrelevant in die werklike betekenis van rooi, wat slegs omskryf kan word as "die kleur wat in die kleurspektrum geleë is tussen geel en infrarooi". Vergelyk hier ook ' $n$ voorbeeld soos die twee betekenisonderskeidinge "oom van vaderskant" en "oom van moederskant" wat vir die leksikale item oom geponeer word, maar wat nie as twee onderskeidende betekeniswaardes van die leksikale item oom beskou word nie.

onbeperkte semantiese variasie vertoon nie; gevolglik kan die parameters van die variasie, instansiërings en afwykings van hierdie parameters en ooreenkomste en verskille ten opsigte daarvan slegs binne taalgebruikskontekste bepaal word.

Die taalgebruiksbenadering impliseer egter by voorbaat dat die hele konteks van witing by die bepaling van die gebruiksbetekenis van 'n leksikale item betrek moet word. Aangesien die buite-grammatikale bydrae van die konteks tot gebruiksbetekeniswaardes deel van die gekonvensionaliseerde betekeniswaarde daarvan kan word, kan daar nie sonder meer 'n onderskeid tussen linguistiese en buite-linguistiese aspekte van 'n betekenisonderskeiding getref word nie. 
' $n$ Tweede tersaaklike voorbeeld is gevalle waar 'n leksikale item referensieel sowel 'n klas/kategorie as 'n onderdeel daarvan denoteer. ' $n$ Voorbeeld hiervan is die gebruik van hond in die betekeniswaardes "familie van hondagtiges" en "reun". Volgens die referensiële kriterium is daar hier nie sprake van meerduidigheid/betekenisonderskeiding nie omdat presies dieselfde gebruiksgevalle wat die klasbetekenis van hond verteenwoordig, volledig saamval met dié wat die subbetekenis "reun" verteenwoordig. Volgens die referensiële benadering verteenwoordig sodanige gebruik van hond 'n geval van vaagheid (aangesien die woord nie gespesifiseer is t.o.v. die onderskeid manlik vs. vroulik nie).

Hierteenoor manifesteer 'n figuurlike en 'n letterlike toepassing van ' $n$ betekenis van ' $n$ woord 'n geval van meerduidigheid, d.i. betekenisonderskeiding. Ter illustrasie: die betekenisverskil tussen rooi in ' $n$ rooi boek en rooi in rooi simpatieë (="in politieke sin links georiënteerd") sal as 'n geval van (polisemiese) meerduidigheid beskou word.

Taylor (1989: 99 e.v.) tref die onderskeid tussen monosemie en polisemie met verwysing na die begrip betekenisdomein. As mens 'n beroep moet doen op verskillende domeine in die definiëring van ' $n$ bepaalde betekenisonderskeiding, of as die gebruik van 'n leksikale item 'n verwysing na verskillende domeine meebring, dan is dit 'n goeie aanduiding dat die betrokke lekseem polisemies is. Skool is hiervan 'n goeie voorbeeld. Van die domeine wat ter sake is, is dié van die opvoeding van kinders en die administratiewe struktuur van 'n universiteit. Die woord vark se betekenis kan mens ook net in terme van verskillende betekenisdomeine ekspliseer: in een betekenis het die woord te make met die klassifisering van diere, in die ander met die eetgewoontes van mense.

In sommige gevalle behels die meerduidigheid van betekenis dat dieselfde domein in terme van verskillende skemas gestruktureer word. Taylor (1989: 100) verwys na die gebruik van hoog in die uitdrukkings 'n hoë plafon en 'n hoë gebou. In altwee hierdie gevalle is die domein dié van vertikale ruimte. Maar in 'n hoë plafon profileer hoog die posisie van 'n entiteit in vertikale ruimte en in 'n hoë gebou die vertikale omvang van 'n entiteit. Volgens Taylor (1989: 100) illustreer die twee uitdrukkings twee verskillende, maar nou verwante betekenisonderskeidinge van hoog. In hierdie geval het mens volgens Taylor dan ook met 'n polisemiese leksikale item te make.

Die verskynsel van die kontekstuele modulasie ${ }^{32}$ van betekenis (vgl. Cruse 1986: 52 e.v.) stel die ondersoeker ook voor die probleem om te bepaal watter betekeniselemente van 'n woord se betekenis tot die woord self behoort en

Taalgebruik vertoon volgens Langacker (1988d: 142) 'n proses van "accommodation, whereby a structure is adjusted to make it compatible with its context", en hierdie aanpassings-inkonteks speel 'n belangrike rol in die ontstaan'van komplekse kategorië̈, d.i. in die ontwikkeling van verdere betekenisonderskeidinge op (n) bestaande betekenisonderskeiding(e). 
watter tot dié van die woorde wat daarmee verbonde is. Kontekstuele modulasie stem ooreen met wat in die kognitiewe raamwerk as die proses van perspektivering geïdentifiseer word. Taylor (1989: 124) gee die volgende voorbeeld: In uitdrukkings soos die volgende word daar telkens 'n ander aspek van 'n motorraam geperspektiveer: ek het die motor laat versien (enjin); ek het die motor gewas (bakwerk); ek het die motor gestofsuig (bekleedsel). In 'n geval soos hierdie word aan vaar dat motor nie polisemies is nie. As toets hiervoor gebruik Taylor die meerduidigheidstoets (wat polisemie sou aandui). Die verskillende geperspektiveerde betekeniskomponente kan in ' $n$ enkele sin saamgevoeg word sonder om zeugma tot stand te bring:

\section{Hulle het die motor gewas, gestofsuig en versien.}

Een van die duideliker toetse vir meerduidigheid bestaan daaruit dat mens een betekenisonderskeiding van ' $n$ woord kan stel en die ander kan ontken. Mens kan bv. beweer dat daar ' $n$ vark (persoon) in jou huis is en terselfdertyd ontken dat daar ' $n$ vark (plaasdier) in jou huis is. Hierteenoor kan mens nie sê dat daar 'n voël (= mossie) op die grasperk sit en terselfdertyd ontken dat daar 'n voël (= volstruis) op die grasperk sit nie.

Ander verfynde toetse om tussen gevalle van vaagheid en meerduidigheid te onderskei, is al voorgestel, maar hulle vereis juis die soort fyn intuitiewe oordele oor die aanvaarbaarheid van uitdrukkings as wat die toetse veronderstel was om te ondervang. Die probleem is verder ook dat gevalle van kontekstuele modulasie die kiem van polisemie bevat sodat taalgebruikers se oordele oor die aanvaarbaarheid van uitdrukkings in 'n groter mate onseker raak.

Alhoewel die onderskeid tussen monosemie en polisemie in beginsel duidelik is, is daar verskeie gevalle waar dit besonder moeilik is, selfs vanuit teoreties-analitiese perspektief, om te besluit of twee verskillende gebruike twee verskillende betekenisonderskeidinge instansieer, of twee eksemplare aanbied van ' $n$ enkele betekenisonderskeiding waarvan die een miskien meer sentraal staan as die ander. Taylor (1989: 100) gebruik hiervoor ook die voorbeeld van die kognitiewe domeine waarteen die woord moeder geprofileer word: die woord moeder kan gebruik word om enigeen van vyf relevante domeine (die geboortedomein, die voedingsdomein, ens.) te perspektiveer. Die vraag is dan of hierdie twee gebruike verskillende betekenisonderskeidinge verteenwoordig. Enersyds perspektiveer hulle inderdaad verskillende domeine, maar aan die ander kant sou mens kon redeneer dat die geperspektiveerde domeine nog steeds verstaan word teen die konteks van die hele matriks van domeine wat prototipiese moeders karakteriseer. Surrogaatmoeders en geboorteskenkende moeders sou hiervolgens dan slegs verskillende soorte moeders wees.

Mens sou kon aanvaar dat die analitiese en intuïtiewe benadering in sommige gevalle tot dieselfde soort strukturele onderskeidinge/oordele oor vaagheid vs. meerduidigheid kan lei, maar intuïtiewe oordele oor betekenisverwantskap respektiewelik -verskil kan ook teenoorgestelde resultate oplewer. 
Een so 'n geval is bv. dié waar 'n lemma ook 'n ondergeskikte term van homself kan wees (vgl. die voorbeeld van hond hier bo). Gegee dat die taalgebruiker vanuit sy breër semantiese kennis oordele oor betekenisverwantskap en -verskil vel, sou mens tewens kon verwag dat die intuïtiewe benadering oordele sal oplewer wat van die teoreties-analitiese kan verskil. Tipiese gevalle sou bv. die volgende wees:

betekeniswaardes wat op intuïtiewe gronde as verskillend beskou word, korreleer met wat vanuit analitiese hoek gevalle van vaagheid eerder as betekenisverskil verteenwoordig; wat intuïtief as 'n enkele betekenisonderskeiding beskou word, word analities in meerdere betekenisonderskeidinge geanaliseer; en intuitiewe betekenisonderskeidinge het 'n enger of breër toepassing/bereik as wat analities onderskei word.

In die praktyk is dit egter sekerlik so dat die leksikograaf hom deur sowel analitiese as intuïtiewe oorweginge in sy afbakening en strukturering van betekenisonderskeidinge laat lei. Soms lei dit daartoe dat hy om analitiese redes allerlei onderskeidinge tref wat vir die gebruiker nie noodwendig almal as aparte betekenisonderskeidinge aandoen nie. Van die gebruiker se kant kan dit gebeur dat hy met betekenisonderskeidinge in die woordeboek gekonfronteer word wat nie duidelik uit die vaaghede van werklike taalgebruikskontekste na vore kom nie, of wat nie psigologies reëel aandoen nie.

Geeraerts (1989a: 57) praat in hierdie verband van die gespanne wisselwerking tussen intuïsie en ontleding in die woordeboek:

Intuitief aangevoelde betekenisverschillen worden referentieel ontleed, de daarbij gehanteerde analytische distincties worden systematisch op de rest van de materiaal toegepast, en zorgen zo voor onderscheidingen die intuïtief al minder voor de hand liggen.

Zgusta $(1971: 47-60 ; 273-275)$ gaan ook uitgebreid op die verskynsel van vaagheid vs. meerduidigheid in. Naas die gevalle van vaagheid hier bo genoem, gee hy ook uitgebreid aandag aan die verskynsel van semanties leë (werk)woorde (sg. "semantic depletion"). Semantiese vaagheid is vir hom een van die primêre oorsake daarvan dat leksikograwe polisemie (betekenisveelheid) poneer waar dit nie voorkom nie, gegee dat gestabiliseerde/gekonvensionaliseerde betekenisonderskeidinge die teiken van die leksikograaf behoort te wees.

Dat mens in beginsel hierdie onderskeid tussen verskillende verskynsels kan tref, impliseer egter nie dat die verskynsels as sodanig in die werklike linguistiese data uitmekaar gehou kan word nie. Zgusta (1971: 68-70) voeg hieraan ' $n$ aantal noodsaaklike byvoegings toe, $n l$. (i) dat die grens tussen gevalle van funksionele meerduidigheid en die semanties leë woorde nie altyd cuide- 
lik is nie (vgl. p. 68, voetnoot 84); (ii) dat gevalle van semanties leë werkwoorde grade van "leegheid" kan vertoon (vgl. p. 69, voetnoot 85) en (iii) dat die onderskeid tussen semantiese leegheid en polisemie nie altyd duidelik sal wees nie (vgl. p. 70); asook die feit (iv) dat sommige semanties leë woorde as leë woorde, maar ook as woorde met 'n volle leksikale betekenis gebruik kan word. As voorbeeld van die laasgenoemde wys hy op die gebruik van take in die sin:

I asked nobody for permission, but simply took it.

Hierby voeg hy dan ook nog dié opmerking:

... let us not forget that quite apart from the depletion, the meaning of a word possesses in any case a certain generality, so that what we might consider single senses are characteristic peaks in the continuum of possible applications. (Zgusta 1971: 70)

Zgusta (1971) se eie uitgangspunt oor watter betekeniswaardes ter sake is in die besluite oor monosemie vs. polisemie relativeer hy egter ook self aan die standpunte van ander leksikograwe en die pragmaties-funksionele vereistes wat woordeboeke stel. Zgusta (1971: 274, voetnoot 159) verwys byvoorbeeld na Shcherba se opvatting "that the dictionary should indicate every single nuance of the lexical unit's meaning" - 'n standpunt wat Zgusta oënskynlik aanvaar, maar soos volg beperk: "this is justifiable only in the case of a big dictionary whose main purpose is to help the user to understand some difficult texts"; en:

It is certainly never easy and sometimes impossible to discern such different applications of a word with a general meaning from a differentiation of its senses; generally, large dictionaries can afford a more extensive ramification of the single senses in their presentation more easily than small ones. (Zgusta 1971: 274)

Bogenoemde hang saam met ' $n$ ander metateoretiese riglyn wat Zgusta (1971: 273) poneer, nl. dat die omvang van die polisemiese geskakeerdheid op die mikrostrukturele vlak van 'n woordeboek moet korreleer met die seleksie van leksikale items op die makrostrukturele vlak. In omvattende woordeboeke sal die keuse van 'n groter aantal lemmas uit die verskillende substrata van die woordeskat gekorreleer wees/moet word met 'n omvangryker weergawe van die polisemiese geskakeerdheid van lemmas. Dialektiese, verouderde en gespesialiseerde betekeniswaardes van leksikale items sal dus bv. ook gelys word in omvattende woordeboeke. In die meer beperkte handwoordeboek wat op die standaardtaal afgestem is, sal streeks-, geografiese, verouderde en ander periferale betekeniswaardes weer nie gelys word nie. 
In die praktyk word daar duidelik nie by net een van hierdie standpunte aangesluit nie - binne ' $n$ enkele woordeboek kan daar meer as een benadering gevolg word. Ter illustrasie: in NWB ('n beperkte woordeboek) word die vae leksikale item toestel eenvoudig gedefinieer as "meganiese hulpmiddel, apparaat, werktuig" en 'n aantal voorbeelde van sodanige toestelle word by wyse van die voorbeeldsinne ingevoer. Hierteenoor word die ewe vae vaartuig gedefinieer deur die ekstensie van dié leksikale item as voorbeelde binne die definisiesin in te voer: "tuig, voorwerp waarmee op water gevaar word, soos 'n skip, boot, skuit, vlot, e.d.m.". In die geval van oom word die bereik van die ekstensie daarvan deur 'n disjunkte definisiesin ingevoer: "broer van die vader of die moeder".

Die kontekstuele nuanses van die semanties leë werkwoord uitgee word uitgebreid beskryf in NWB:

1. (geld) bestee.

2. ('n boek) publiseer.

3. (lig, hitte) uitstraal.

4. ... voorgee, maak asof. Hom - vir 'n Fransman.

Die onderskeid tussen monosemie en polisemie en tussen homonimie en polisemie kan met 'n 'n aantal duidelike gevalle geillustreer word, maar mens het hier met 'n groot verskeidenheid onduidelike gevalle te make. Die probleem is natuurlik dat verwantskap van betekenis 'n gegradeerde en subjektiewe begrip is en dat die taalondersoeker dikwels nie duidelike gevalle van taalgebruik tot sy beskikking het wat agterhaalbare oordele van verwantskap of verskil duidelik illustreer nie.Verskeie taalkundiges het dan ook al daarop gewys dat die onderskeid tussen monosemie en polisemie en dié tussen polisemie en homonimie nie in digotome terme verstaan moet word nie maar eerder as punte op 'n kontinuum. Duidelike gevalle van elke soort verskynsel vorm die eindpunte van so 'n kontinuum, maar tussenin val al die ander gevalle waar die grens nie so duidelik getref kan word nie.

So 'n skalêre benadering maak in elk geval vanuit diachroniese oogpunt sin omdat duidelike betekenisonderskeidinge met verloop van tyd kan versmelt, en omgekeerd kan duidelik verskillende betekenisonderskeidinge met verloop van tyd uit 'n enkele betekenisonderskeiding ontwikkel. Sinchronies het jy altyd met fases in hierdie prosesse te make sodat jy kan verwag om met tussengevalle gekonfronteer te word.

Vanuit leksikografiese perspektief sou mens ook 'n argument daarvoor kon uitmaak dat woordeboeke nie net sg. betekenisonderskeidende waardes van 'n leksikale item moet lys nie omdat die taalgebruiker met taalgebruik in konteks gekonfronteer word en dat hy intuïtief in die bepaling van die aantal betekeniswaardes wat 'n leksikale item sou hê, nie die onderskeid tussen betekenisonderskeidinge en kontekstuele toepassinge sistematies handhaaf nie. 


\subsubsection{Die lineariteitsprobleem}

Zgusta (1971: 278-280) gee uitgebreid aandag aan wat Geeraerts (1990a: 198) die "lineariteitsprobleem" noem, d.i. hoe om die wesentlik multidimensionele struktuur van 'n prototipies georganiseerde konsep op die basiese lineêre ordening (van die geskrewe teks) van betekeniswaardes in 'n woordeboekartikel af te beeld. Die probleem ontstaan daarin dat in die woordeboekartikel slegs ' $n$ lys afgebakende, opeenvolgende betekeniswaardes weergegee word, terwyl die betekeniswaardes van prototipiese konsepte bestaan uit geklosterde en deels oorvleuelende betekenisonderskeidinge.

Zgusta wys ook op die feit dat die gewone lysting van betekenisonderskeidinge nie die wesentlike semantiese verwantskappe/relasies tussen betekeniswaardes kan aandui nie:

The sequential presentation in the dictionary is necessarily linear, so that these different dimensions cannot be indicated; that does not, however, matter too much since it is really not necessary to express all these intricacies in the presentation. (Zgusta 1971: 280)

Zgusta (1971: 282) voeg dan ook 'n gepaste waarskuwing by:

When he prepares this articulation of the entry, the lexicographer must be aware of the fact that he is not preparing a logical classification of notions nor a scientific systematization of classes; he must stick exclusively to what he finds in the linguistic facts and present lexical meaning as a continuum the articulations of which may be strange, or insufficient or overlapping or disconnected.

Geeraerts (1990a) toon egter aan dat die aanbieding van die verskillende betekeniswaardes van ' $n$ polisemiese leksikale item in handwoordeboeke as 'n genommerde lys van aparte betekenisonderskeidinge die indruk skep dat die betekenisonderskeidinge van ' $n$ lemma na hulle referensiële toepassingsgebied maksimaal geskei kan word. Die praktyk om genommerde betekenisonderskeidinge in 'n linêre opeenvolging weer te gee, bring mee dat daar in die struktuur van die woordeboekartikel geen aanduiding van die oorvleuelende aard van betekenisonderskeidinge gegee word nie. Alhoewel hierdie werkwyse in handwoordeboeke nie die leksikografiese ordening by uitstek beliggaam nie, dra dit baie by tot die verspreiding van ' $n$ naïewe beeld van leksikaal-semantiese struktuurverhoudinge. Soos Geeraerts (1990a: 205) egter tereg opmerk, impliseer hierdie aanbiedingswyse ook nie dat die leksikografie gestuur word deur 'n opvatting van leksikale polisemie waarin daar aan die probleme van periferale en afwykende betekenisonderskeidinge verbygegaan word nie. 
Die lineariteitsprobleem doen hom egter veral voor in die geval van groter omvattende verklarende woordeboeke (soos die WAT) waarin die leksikograaf poog om so 'n getrou en omvattend as moontlike beskrywing te gee van die polisemiese geskakeerdheid van 'n polisemiese leksikale item: veel meer gebruikstoepassinge, -nuanses en minder frekwente betekeniswaardes sal dus ook in die woordeboekartikel opgeneem word sodat die klostering en oorvleueling van betekeniswaardes maksimaal sal wees en gevolglik ook struktureel afgebeeld sou moes kon word.

In die weergawe van die polisemiese geskakeerdheid van leksikale items in die omvattende woordeboek kan die leksikograaf volgens Geeraerts (1990a) egter verskillende opsies volg: hy kan eenvoudig die verskillende betekenisonderskeidinge, -toepassinge en -nuanses lys, of hy kan, in ooreenstemming met die ontledingspraktyk om oor sekere onderskeidinge en nuanseringe te veralgemeen, slegs die hoërvlakgroeperinge (in die vorm van oorkoepelende definisies) weergee. Geeraerts (1990a: 204) wys egter daarop dat sowel die navolg van die een as die ander metode deskriptief onvoldoende is. Indien mens slegs die hoërvlakabstraksies weergee, verberg mens die intuïtief geldige onderskeidinge binne daardie hoofgroepe. Spesifiseer mens slegs die laevlakwaardes, dan ontken mens daarmee dat sommige van hierdie gevalle vanuit 'n definisionele oogpunt onder meer algemene definisies ondergebring kan word. Vanuit die oogpunt van beskrywende adekwaatheid lê die oplossing dus daarin dat altwee hierdie benaderings gevolg moet word, d.i. 'n beskrywing van én die basiese betekeniswaardes én die hoërvlakgroeperinge waartoe hulle aanleiding gee. En dit impliseer ' $n$ beskrywing van die geklosterde aard van hierdie groeperinge.

Leksikograwe het egter allerlei tegnieke om die lineariteitsprobleem te oorkom. Die eerste hiervan is volgens Geeraerts (1990a: 206) om 'n hiërargiese struktuur op die semantiese materiaal te superponeer met ' $n$ aanduiding van die relasies tussen die hoërvlakonderskeidinge en hulle periferale waardes. So 'n hiërargie kan besonder diep loop.

'n Struktuur van hierdie aard sal egter nog steeds naby staan aan die klassieke opvatting van semantiese strukture, in die besonder die opvatting dat rigiede grense tussen verskillende toepassings van 'n konsep gehandhaaf kan word. Die punt is dat die netheid en rigiditeit van die hiërargie nie die semantiese struktuur van 'n konsep op adekwate wyse weergee nie aangesien sulke omvattender groeperinge van 'n prototipiese konsep nie die vorm van ' $n$ taksonomie aanneem nie, maar juis 'n geheel van veelvoudige oorvleuelinge en onsekere grense. Die taksonomiese strukturering van die data beliggaam egter wel die noodsaak om hoërvlakgroeperinge saam met basiese spesifikasies te beskryf. Andersyds impliseer dit egter dat elkeen van die hiërargiese subversamelings rigied gedefinieerd is met geen onderlinge oorvleueling nie.

Uit die ontleding van die struktuur van woordeboekartikels blyk dit egter duidelik dat leksikograwe hiërargiese strukture op 'n nie-taksonomiese wyse gebruik om die onbepaaldheid en oorvleueling in die hiërargiese groeperinge 
aan te dui. Verskillende tegnieke bestaan hiervoor, waarvan elke woordeboek sy eie besondere stelsel selekteer. Geeraerts (1990a: 208-209) wys ten opsigte van die WNT daarop dat 'n verskeidenheid tegnieke ingespan word.

Kruisverwysings na ander dele van die hièrargiese struktuur word ingevoer om onderlinge verwantskappe tussen betekenisonderskeidinge, -nuanses en -toepassinge aan te dui. Hierdie kruisverwysingstegniek behels egter ook dat sekere definisies aangebied word as 'n konjunksie van die betekeniswaardes/konsepte wat deur ander definisies beskryf word. Hieruit volg dat sekere definisies eksplisiet as konjunksies geformuleer word van konsepte wat in ander betekenisonderskeidinge ter sake is. Geeraerts se eie voorbeeldmateriaal suggereer egter dat hierdie konjunktiewe betekenisonderskeidinge ' $n$ bepaalde (komplekse) konsep vorm wat as sodanig geaktiveer kan word in 'n taalgebruikskonteks, m.a.w. dat die konjunkte definisie nie eenvoudig net 'n analitiese hoëvlakabstrahering is wat oor hierdie onderskeie konsepte veralgemeen nie.

Hierdie aspek kan soos volg verduidelik word n.a.v. Geeraerts se ontleding van die woord vers (Afr. vars). ${ }^{33}$ (Vgl. ook die bespreking hier bo.) Vars word prototipies op voedsel van toepassing gemaak in welke geval dit ' $n$ betekeniswaarde het "resent geproduseer en in optimale toestand vir gebruik". Hierdie betekenisonderskeiding is egter self saamgestel uit twee konsepte wat ook onafhanklik geaktiveer kan word, nl. "in 'n optimale toestand" en "nuut, resent". Eersgenoemde oorkoepelende definisie is dus 'n konjunksie van twee ander betekeniswaardes van vars sodat dit as verwysing vir die ander twee konsepte dien.

Alhoewel die eerste betekenisonderskeiding van vars volgens Geeraerts (1990a: 205) werklik betekenisonderskeidend is, is lg. twee volgens hom gevalle van vaagheid wat onder die eerste betekenisonderskeiding ondervang sou kon word. Hierdie verdeling geld egter net vanuit ' $n$ analitiese oogpunt, maar nie vanuit ' $n$ intuïtiewe oogpunt nie omdat die meeste sprekers al drie hierdie betekeniswaardes as verskillende waardes van die betrokke leksikale item vars sal beskou. ' $n$ Woordeboekartikel wat al drie hierdie betekeniswaardes lys, gee dus die polisemiese geaardheid van die betrokke leksikale item weer vanuit sowel 'n analitiese as 'n intuitiewe oogpunt.

Die bestaan van vae grense en ligafwykende gebruikstoepassinge of -nuanses word op die volgende manier gesinjaleer: 'n kernbetekenis word vir 'n groep betekeniswaardes verskaf, bestaande uit (van) die betekeniskomponente wat lede binne die groep deel. Hiermee word dus gesinjaleer dat die verskillende betekeniswaardes met mekaar oorvleuel. Vgl. in hierdie verband weer die voorbeeld van vars hier bo.

Die tweede tegniek wat gevolg word, is dat betekeniswaardes saamgroepeer word wat wel met mekaar verband hou, maar wat meestal nie eenduidig

Vgl. in hierdie verband ook die struktuurontleding van die woordeboekartikel vir die lemma vers in die WNT in Geeraerts (1988c). 
deur 'n enkele betekenisdefinisie oorkoepel kan word nie, d.i. die spesifisiteit van die byeengeplaaste betekenisonderskeidinge word nie voldoende deur hierdie gemeenskaplike betekenis ondervang nie.

So 'n definisie van 'n gemeenskaplike of kembetekenis moet egter so geïnterpreteer word dat al die betrokke lede nie noodwendig identies is ten opsigte van die kenmerke wat in die definisie vermeld word nie, maar wel as nuanses van die sentrale betekenis (wat in die superordinaatdefinisie verskaf word). Die subordinate betekeniswaardes word in gevalle soos hierdie saamgroepeer op grond van ooreenkoms eerder as streng identiteit ten opsigte van die superordinaatdefinisie: die superordinaatdefinisie spesifiseer net die basis van hulle ooreenkoms, nie die basis van hulle identiteit nie. In 'n gewone taksonomiese struktuur word daar gewoonlik aanvaar dat die subordinaatdefinisies kenmerke of konsepte aan die superordinaatdefinisie toevoeg (d.i. tussen hulle is daar 'n skema-instansiëringsrelasie - vgl. die bespreking hieronder). Maar volgens die prototipiese opvatting hoef die subordinaatbetekeniswaardes nie al die kenmerke te besit wat in die superordinaatdefinisie aangedui word nie aangesien hulle lidmaatskap van die kategorie kan steun op ooreenkoms eerder as op taksonomiese identiteit. Die kernbetekenis wat op hierdie wyse geabstraheer word, moet dus nie in die essensialistiese sin vertolk word nie.

Die nie-taksonomiese groepering van betekeniswaardes word ook bereik deur die gebruik van disjunktiewe definisies wat self kombinasies is van ooreenstemmende, maar aparte konsepte. Konsepte word in sulke definisies gekoppel met 'n aanduiding soos en/of, opsionele elemente word in definisies ingevoer en tussen hakies geplaas en oop lyste word opgeneem sodat die definisie as sodanig as disjunktief eerder as essensialisties vertolk moet word. Geeraerts (1990: 207) gee die volgende voorbeeld:

Recently produced and hence, through its taste and/or its nutritive value (pre-eminently) suited for consumption; recently harvested, caught, killed, prepared, etc, and hence not yet subject to decay.

Ook in 'n geval soos hierdie lê ooreenkoms, wat variasie en afwyking in aanmerking neem, aan die basis van die definisie en nie eenvoudig ' $n$ taksonomiese relasie wat essensialistiese identiteit impliseer nie.

'n Algemene tegniek wat ook gevolg word, is dat 'n besonder vae oorkoepelende definisie van 'n hoofbetekenisonderskeiding verskaf word, maar dat dit dan nader gepresiseer word vir die verskillende betekenisnuanses waaroor dit veronderstel is om as veralgeming te dien. In die WNT word sulke meer spesifieke waardes ingelui met ' $n$ frase soos Ook wel m.betr.t. wat ligte betekenisvariante verteenwoordig wat nie sodanig van die sentrale betekenis afwyk dat hulle as aparte betekenisonderskeidinge opgeneem word nie. In die WNT word hierdie kategorie ook ingelui met frases soos hierbij ook, vandaar, in de volgende aanh., soms ook zooveel als. 
Dit is nie altyd moontlik om die onderskeide nuanses goed uiteen te hou nie (in die WNT soms gesinjaleer met ' $n$ frase soos In sommige aanhalingen moeilijk te scheiden van ...). Hieruit blyk duidelik dat die verskillende betekenisnuanseringe en -onderskeidinge nie dieselfde strukturele gewig het of kry in 'n woordeboekartikel nie. Sulke gebruikstoepassinge en moeilik onderskeibare nuanses het minder strukturele gewig as die betekenisonderskeidinge wat onder die hoofnommers saamgevat word.

Ten slotte is daar ' $n$ aantal strukturele tegnieke wat leksikograwe inspan om aan te dui dat hiërargies gegroepeerde betekeniswaardes prototipies verwant is, eerder as taksonomies identies. Struktureel word toepassinge en -nuanses van hoofonderskeidinge by daardie groep as subgroep ingedeel en duidelik as subordinaat aan die hoofonderskeiding geplaas. In hierdie geval is die subordinate plasing nie 'n aanduiding van 'n taksonomiese relasie nie, maar van nabye verwantskap wat van ware identiteit onderskei moet word. In die geval van metonimiese uitbreidings word sulke toepassinge eksplisiet met etikette as metonomies gemerk, wat onderstreep dat hulle op basis van metonimie eerder as verwantskap met mekaar verband hou.

Kortom: die ontleding van die strukturering van woordeboekartikels in omvattende woordeboeke toon dat nóg 'n klassiek lineêre, nóg 'n semi-klassieke taksonomiese model gevolg word. Eerder is dit so dat hiërargiese struktuur gebruik word om die spanning tussen analitiese en intuitiewe oordele oor betekenisonderskeidinge uit te druk, d.i. deur sowel basiese betekeniswaardes as hoërvlakgroeperinge te inkorporeer. Daarby word die hiërargiese struktuur op verskillende punte aangepas om die onbepaaldheid en klostering in groepe aan te dui.

\section{Kategorisering deur skematisering}

Daar bestaan ook konseptuele skakels tussen die lede van subkategorieë, subkategorieë onderling en oor kategoriegrense heen wat op gedeeltelike insluiting berus en waarvoor ' $n$ kategoriemodel wat net in terme van sentrale en periferale lede gekonsipieer is, nie afdoende is nie. Langacker $(1987,1988 \mathrm{a}-\mathrm{d})$ se model van kategoriestruktuur is 'n sintese van die prototipeteorie en kategorisering wat op skemas berus, d.i. 'n struktuur wat ook vir gedeeltelike insluiting as basis vir kategorieverwantskap voorsiening maak.

Langacker (1987: 371) vat die onderskeid tussen die begrippe prototipe en skema soos volg saam:

A prototype is a typical instance of a category, and other elements are assimilated to the category on the basis of their perceived resemblance to the prototype; there are degrees of membership based on degrees of similarity. A schema, by contrast, is an abstract characterization that is fully compatible with all the members of the category it defines (so membership is not a matter of degree); it is an 
integrated structure that embodies the commonality of its members, which are conceptions of greater specificity and detail that elaborate
the schema in contrasting ways.

Langacker (1987) gebruik die term skema dus om te verwys na die abstrakte representasie van wat lede van 'n kategorie gemeen het (vgl. Taylor 1989: 85, voetnoot 2). Instansiërings van skemas sluit altyd die inhoud van die skema in, maar hulle kan ook konsepte insluit waarna die skema self geen verwysing maak nie. 'n Skema kan dus slegs ' $n$ veralgemening wees oor ' $n$ deel van die inhoud van die instansiërings daarvan.

Skematisering word ook gedefinieer as die relasie tussen superordinaatknope en subordinaatknope in 'n taksonomiese hierargie of 'n netwerk (Langacker 1988c: 91). Die kerngedagte is dat een element (die superordinaat) as ' $n$ skema tot die ander item (subordinaat) staan of dat laasgenoemde as ' $n$ instansiëring van 'n bepaalde skema dien. Hierdie begrippe word skematies soos volg uitgedruk:

$$
((X) \rightarrow(Y))
$$

Hier verteenwoordig die pyl die oordeel dat een struktuur as skema vir die ander dien, met $X$ as die strukturele eenheid wat as skema dien en $Y$ as die eenheid wat as instansiëring van die skema dien.

In die geval van kategorisering op grond van die prototipe is enige instansiëring slegs gedeeltelik in ooreenstemming met die prototipe as abstrakte mentale representasie, of dit kan selfs, vanweë die familieverwantskapstruktuur, geen kenmerke met die prototipe deel nie. Kategorisering op grond van prototipes en kategorisering op grond van skemas maak ook verskillende voorspellings oor lidmaatskap: in eersgenoemde geval is lidmaatskap gegradeerd, in laasgenoemde geval nie.

Skematiese strukture verrig drie funksies: (i) hulle ondervang reëlmatighede deur die gemeenskaplike of reëlmatige aspekte van 'n verskynsel uit te druk; (ii) hulle bied die basis vir kategoriseringsrelasies waarin die status van spesifieke leksikale items ten opsigte van strukture en patrone van groter algemeenheid aangetoon word; en (iii) hulle bied die basis vir die afleiding van die interpretasie van nuwe uitdrukkíngs (maar hulle karakteriseer nooit volledig die volle semantiese inhoud van 'n spesifieke leksikale item nie) (vgl. Langacker 1988a: 25-26). ${ }^{34}$

Schemas capture generalizations by representing pattems observable across expressions. Unit instantiations of constructional schemas (both specific expressions and subschemas at varying levels of abstraction) describe the actual implementation of these generalizations by specifying their conventional range of application. (Langacker 1988a: 30) 
In die ontleding van die struktuur van polisemiese kategorieë is die onderskeid tussen die prototipe van 'n kategorie en dit wat as skemas geponeer word van belang vir sover as wat hierdie twee nie altyd hoef saam te val nie. in Illustrasie hiervan is die verskillende betekenisonderskeidinge wat in Afrikaans vir die werkwoord vra onderskei kan word in die een hoofbetekenisonderskeidinge daarvan, ${ }^{35} \mathrm{nl}$. die stel van ' $\mathrm{n}$ vraag (vgl. byvoorbeeld wat NWB as eerste betekenisonderskeiding van vra gee: "'n vraag of vrae stel").

Soos die onderstaande toon, word vrae nie net gevra om antwoorde te ontlok nie. Verdere subverdeling van die klas is moontlik omdat vrae gevra kan word met verskillende doelstellinge in die oog, waarvan 'n werklike soeke na inligting slegs een is. 'n Verdere subverdeling van die kategorie is moontlik op grond van bv. verskille in die intensies en verwagtings van sprekers en hoorders met die stel van vrae. Die een kenmerk wat die betekeniswaardes in die hele kategorie egter deel, is die stel van 'n vraag, wat die hele subkategorie as sodanig bymekaarhou. Vir hierdie subkategorie kan daar dan 'n semantiese skema geabstraheer word, nl. STEL 'N VRAAG, waarop die ander instansiërings verskillende grade van spesifisiteit kan vertoon.

$\mathrm{Vgl}$. in hierdie verband die onderstaande betekenisonderskeidinge vir vra. Duidelikheidshalwe word die betekeniswaardes in die vorm van sinstukke weergegee. By elke betekenisonderskeiding word, waar gepas, ook een of meer voorbeeldsinne verskaf wat as instansiëring daarvan geld.

a.

STEL N VRAAG

Moet ek jou vraag namens jou vra?

b. (STEL 'N VRAAG) MET EEN OF ANDER INTENSIE/BEGEERTE EN VERWAG VAN DIE HOORDER OM TE ANTWOORD OF NIE

Hy sal mens nooit 'n vraag vra waarvan hy nie self die antwoord weet nie.

Om die gesels aan die gang te kry, het hy 'n paar vrae gevra oor sy familie.

Heelwat vrae is in die ondersoek gevra.

Vrae word in die Parlement gestel.

En:

By its very nature, a high-level schema is compatible with a broad and structurally diverse array of potential instantiations. Typically, however, conventional usage carves out for exploitation only limited regions within this field of structural possibilities. A full linguistic description must identify these regions, i.e. it must characterize the construction's conventional domain, as articulated by a hierarchy of lower-level structures. Providing this information are subschemas and expressions with the status of units: they specify the actual array of subcases and specific instances that support and give rise to the high-level generalization. (Langacker 1988d: 152)

Die ontleding van die Afrikaanse data is hier aangepas na Rudzka-Ostyn (1989) se ontleding van die betekeniskompleks van ask in Engels. 
Lede kan enige vraag vra wat hulle wil.

c. (STEL 'N VRAAG) EN DRUK DAARMEE DIE BEGEERTE UIT OM TE HOOR WAT MENS NIE REEDS WEET NIE, WAARVAN JY KAN AANNEEM DAT DIE AANHOORDER DIT WEET, EN VERWAG VAN HOM OM DIT MEE TE DEEL

"Wat wil jy hê moet ek doen?" het Piet gevra.

Hy het gevra of sy weet waar Sarie is.

Toe vra hy my wat ek in Berlyn doen.

d. (STEL ' $N$ VRAAG) MET DIE DOEL OM UIT TE VIND OF DIE AANHOORDER ' $N$ ANTWOORD HET EN VERW AG DAN EEN OF ANDER VERBALE REAKSIE VAN HOM.

e. (STEL 'N VRAAG) MET DIE DOEL OM DIE ANTWOORD TE REGISTREER, AANVAAR DAT DIE HOORDER DAAROOR BESKIK EN VERWAG VAN HOM OM DIT TE VERSKAF.

f. (STEL ' $N$ VRAAG) MET DIE DOEL OM DIE AANHOORDER SE AANDAG TE VESTIG OP ' $N$ TOESTAND, PROBLEEM OF VERONDERSTELDE FEIT; VERWAG SOMS VAN DIE HOORDER 'N VERBALE ANTWOORD

As mens vra wat die oplossings vir hierdie land behoort te wees, dan is daar verskeie opsies oop.

Daar sal in die besonder gevra word hoe ons hierdie probleem kan oplos. Dit sal mens egter lei na die verantwoordelikhede van elkeen van ons.

g. (STEL 'N VRAAG) EN DRUK DAARMEE DIE BEGEERTE UIT OM VERTEL TE WORD WAT MENS NIE WEET OOR DIE TOESTAND, GESONDHEID, ENS. VAN IEMAND NIE; AANVAAR DAT DIE AANHOORDER DIT WEET EN VERWAG VAN HOM OM DIT MEE TE DEEL.

Jou oom het na jou welstand gevra, Piet.

h. (STEL 'N VRAAG) EN DRUK DAARMEE DIE BEGEERTE UIT OM INLIGTING VERSKAF TE WORD (EN VERWAG DIT AS SODANIG) OOR 'N VOORNEMENDE HANDELING.

Hy het gevra hoe dit gedoen moet word.

Indien mens vir eers die probleem met die subtiele betekenisonderskeidinge hier bo laat, dan blyk dit dat die verskillende betekeniskomponente van hierdie leksikale item hiërargies georden kan word in terme van die wyse waarop hulle as skemas ten opsigte van mekaar funksioneer; vgl. die onderstaande: 


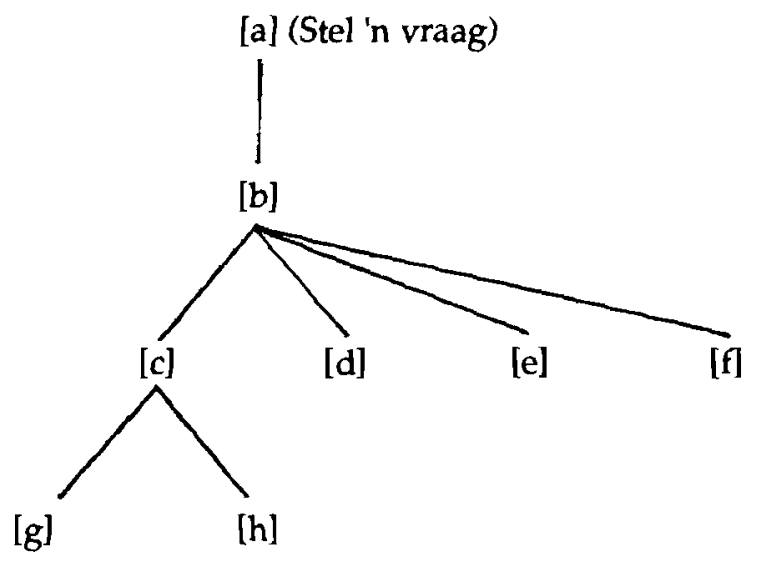

Verdere differensasie binne die subkategorie is dus moontlik en verskillende sodanige skemas kan geïdentifiseer word vir die reeks subgevalle, wat 'n hiërargies geordende netwerk vorm. In gevalle soos hierdie ondervang hoërliggende skemas as veralgemenings egter die gemeenskaplike betekeniskomponente van die subordinate instansiërings. In die bostaande spesifiseer [g] en [h] in groter besonderhede die inligting wat 'n primêre spreker verlang. Op hulle beurt vul $[c],[d],[e]$ en [f] in meer besonderhede die spreker se intensies in, wat in [b] as ' $n$ relevante, maar meer abstrakte komponent weergegee word.

In hierdie konseptuele kloster is [c] egter die prototipe van die kompleks as 'n geheel, d.w.s. dit is die betekeniswaarde wat moedertaalsprekers as die dominante betekenis van vra beskou (Rudzka-Ostyn 1989: 624-625). Die betekenis daarvan kan omskryf word as "stel 'n vraag met die doel om inligting te bekom", wat konseptueel-inhoudelik ooreenstem met die eerste gedeelte van HAT se eerste betekenisonderskeiding vir vra, nl. "Jou tot iemand rig deur woorde om iets van hom te wete te kom, hom iets te laat sê; 'n vraag doen". As [c] as die sentrale lid van die subkategorie aanvaar word, dan impliseer dit dat die ander as periferale lede beskou moet word. Die periferale lede word egter almal aan die sentrale prototipe verbind deur die gemeenskaplike betekenis wat die kategorie as 'n geheel bymekaar hou, nl. "stel 'n vraag".

Verder berus die verbintenis tussen [c] as sentrale lid en die periferale lede [a], [b], [g] en [h] op skematisering. Die periferale lede [d], [e] en [f] is aan die prototipe verbind deur die aanwesigheid van die gemeenskaplike betekeniskomponente [a] en [b].

Ten opsigte van sprekersintensies en verwagtinge staan [d] en [e] nader aan die prototipe as [f] aangesien beide uitdrukking gee aan die begeerte om inligting (alhoewel met verskillende motiewe). In die geval van [f] is daar geen begeerte van die spreker se kant om iets van die aanhoorder te wete te kom nie - eintlik wil die spreker aan die hoorder iets oordra. [a], waarin alle konsepte van intensionaliteit en begeerte ontbreek, het ook periferale status. Hierteen- 
oor berus die periferale status van $[\mathrm{g}]$ en [h] daarop dat hulle te beperkend (ten opsigte van die prototipe is); [b], daarenteen, is weer te algemeen.

Die vraag is nou wat die status van 'n abstrakte skema soos [a] is, d.i. of dit inderdaad as konseptuele komponent geaktiveer word met die gebruik van vra. Volgens Rudzka-Ostyn (1989: 629) is dit die relevante betekeniswaarde wat geaktiveer sou word in ' $n$ sin soos

'n Klomp vrae is in die De Klerk-Treurnicht-debat gestel

waarin die intensiekomponent vaag of onuitgedruk is. ${ }^{36}$ 'n Verdere verskynsel wat hierdeur geillustreer word, is dat die prototipiese betekenis as die betekenis van die kategorie verskaf word. Hierdie verskynsel beklemtoon die belang van metonimiese modelle in die funksionering van taal. Die prototipe verteenwoordig in 'n geval soos hierdie die kategorie as 'n geheel.

\section{Slot}

In die voorafgaande is daar duidelik getoon dat die metaleksikografiese riglyne in Zgusta (1971) in beginsel in baie opsigte ten nouste by uitgangspunte van die prototipeteorie, soos uiteengesit, aansluit. Maar daar is ook telkemale getoon dat die prototipiese perspektief allerlei nuwe weë open van waaruit bestaande leksikografiese probleme. benader en 'n meer adekwate metaleksikografie gekonsipieer kan word.

Uiteraard het hierdie verkenning sy beperkinge. Baie van die ooreenkomste en verskille wat hier aan die orde gestel is, sal nog in diepte ondersoek moet word - sowel na die kant van die prototipeteorie as na die kant van die leksikografieteorie en -praktyk toe. Die hoop is egter dat hierdie verkenning met verdere ondersoek meer gesubstansieer en verder verfyn sal kan word.

\section{Bronnelys}

\section{Woordeboeke}

HAT F.F. Odendal (Red.). 1979. Verklarende Handwoordeboek van die Afrikaanse Taal. Doomfontein: Perskor.

NWB M. de Villiers et al (Reds.). 1987. Nasionale Woórdeboek. Kaapstad: Nasou.

WAT P.C. Schoonees/F.J. Snijman/D.C. Hauptfleisch (Reds.). 1950. Woordeboek van die Afrikaanse Taal. Pretoria: Staatsdnukker.

36 Volgens Rudzka-Ostyn (1989) kan die bestaan/gigeldigheid van elkeen van hierdie betekeniswaardes verder aangetoon word indien daar met elkeen van die relevante betekenisonderskeidinge ook ' $n$ verskillende sintakties-formele patroon korreleer. 
WNT M. de Vries et al (Reds.). 1882-. Woordenboek der Nederlandsche Tanl. Den Haag: Nijhoff.

\section{Aangehaalde werke}

Ayto, J.R. 1983. On Specifying Meaning. Hartmann, R.R.K. (Red.). 1983: 89-97.

Bartsch, R. 1987. Norms in Language. Londen: Longman.

Brówn, C.H. 1990. A Survey of Category Types in Nahural Language. Tsohatzidis, S.L. (Red.). 1990: 17-47.

Cruse, D.A. 1986. Lexical Semantics. Oxford: Oxford University Press.

Dirven, R. en J.R. Taylor. 1988. The Conceptualization of Vertical Space in English: The Case of Tall. Rudzka-Ostyn, B. (Red.). 1988: 379-402.

Geeraerts, D. 1983a. Ontwikkelingen in de lexicografische theorievorming. Jaarboek ban de Stichting INL. 1981-1982: 56-65.

Geeraerts, D. 1983b. Prototype Theory and Diachronic Semantics. Indogermanische Forschungen 88: 1-32.

Geeraerts, D. 1983c. Lexicografie en linguïstiek: Reichling gerehabiliteerd. Tijdschrift voor Nederlandse Taal-en Letterkunde 99: 186-206.

Geeraerts, D. 1984a. Type en prototype. TTT: Interdisciplinair Tijdschrift voor Tekst- en Taalwetenschap 4: 69-86.

Geeraerts, D. 1984b. Dictionary Classification and the Foundations of Lexicography. ITL: Reoiew of Applied Linguistics, 63: 37-63.

Geeraerts, D. 1985a. Preponderantieverschillen bij bijna-synoniemen. De Nieuwe Taalgids 78: 18-27.

Geeraerts, D. 1985b. Diachronic Extensions of Prototype Theory. Hoppenbrouwers, G. et al (Reds.). 1985: 354-362.

Geeraerts, D. 1986. Woordbetekenis: Een overzicht oan de lexicale semantiek. Leuven: Acco.

Geeraerts, D. 1987a. Types of Semantic Information in Dictionaries. Ilson, R. (Red.). 1987: 1-10.

Geeraerts, D. 1987b. On Necessary and Sufficient Conditions. Journal of Semantics 5: 275-291.

Geeraerts, D. 1988a. Cognitive Grammar and the History of Lexical Semantics. Rudzka-Ostyn, B. (Red.). 1988: 647-677.

Geeraerts, D. 1988b. Where Does Prototypicality Come From? Rudzka-Ostyn, B. (Red.). 1988: 207229.

Geeraerts, D. 1988c. Prototypicality as a Prototypical Notion. Communication and Cognition 21: 343-355.

Geeraerts, D. 1989a. Wat er in een woord zit: Facetten zan de lexicale semantiek. Leuven: Peeters.

Geeraerts, D. 1989b. Introduction: Prospects and Problems of Prototype Theory. Linguistics 27: $587-612$.

Geeraerts, D. 1989c. Principles of Monolingual Lexicography. Hausmann, F.J. et al (Reds.). 1989: 287-296.

Geeraerts, D. 1990a. The Lexicographical Treatment of Prototypical Polysemy. Tsohatzidis, S.L. (Red.). 1990: 195-210.

Haiman, J. 1980. Dictionaries and Encyclopedias. Lingua 50: 329-357.

Hartmann, R.K.K. (Red.). 1983. Lexicography: Principles and Practice. Londen: Academic Press. 
Hausmann, F.J. et al (Reds.). 1989. Wörterbücher, Dictionaries, Dictionnaires: Ein internationales Handbuch zur Lexikographie; An International Encyclopedia of Lexicography; Encyclopédie internationale de lexicographie. Berlyn: Walter de Gruyter.

Hoppenbrouwers, G. et al (Reds.). 1985. Meaning and the Lexicon. Dordrecht: Foris.

Hyldgaard-Jensen, K. en A. Zettersten (Reds.). 1988. Symposium on Lexicography: Proceedings of the Third Intemational Symposium on Lexicography May 1416, 1986 at the University of Copenhagen. Tübingen: Max Niemeyer.

Ilson, R. (Red.). 1987. A Spectrum of Lexicography. Amsterdam: John Benjamins.

Lakoff, G. 1987. Women, Fire and Dangerous Things: What Categories Reveal about the Mind. Chicago: University of Chicago Press.

Landau, S. 1984. Dictionaries: The Art and Craft of Lexicography. New York: Scribners.

Langacker, R.W. 1987. Foundations of Cognitive Grammar. Vol. 1: Theoretical Prerequisites. Stanford: Stanford University Press.

Langacker, R.W. 1988a. An Overview of Cognitive Grammar. Rudzka-Ostyn, B. (Red.). 1988: 3-48.

Langacker, R.W. 1988b. A View of Linguistic Semantics. Rudzka-Ostyn, B. (Red.). 1988: 49-90.

Langacker, R.W. 1988c. A Usage-based Model. Rudzka-Ostyn, B. (Red.). 1988: 127-161.

Lehrer, A. 1989. Polysemy, Conventionality and the Structure of the Lexicon. Duisburg: LAUD Series A240.

Lehrer, A. 1990. Prototype Theory and its Implications for Lexical Analysis. Tsohatzidis, S.L. (Red.). 1990: 368-381.

Lyons, J. 1977. Semantics. Vol. 1 and 2. Cambridge: Cambridge University Press.

Persson, G. 1988. Homonymy, Polysemy and Heterosemy: Three Types of Lexical Ambiguity in English. Hyldgaard-Jensen, K en A. Zettersten (Reds.). 1988: 269-280.

Rosch, E. en C.B. Mervis. 1975. Family Resemblances: Studies in the Internal Structure of Categories. Cognitioe Psychology 7: 573-605.

Rudzka-Ostyn, B. (Red.). 1988. Topics in Cognitioe Linguistics. Amsterdam: John Benjamins.

Rudzka-Ostyn, B. 1989. Prototypes, Schemas, and Cross-category Correspondences: The Case of Ask. Linguistics 27(4): 613-661.

Swanepoel, P. 1990. Definisies in vakkommunikasie. Pretoria: RGN.

Sweetser, E. 1990. From Etymology to Pragmatics: Metaphorical and Cultural Aspects of Semantic Structure. Cambridge: Cambridge University Press.

Taylor, J.R. 1989. Linguistic Categorization: Prototypes in Linguistic Theory. Oxford: Clarendon Press.

Traugott, E.C. 1985. On Regularity in Semantic Change. Journal of Literary Semantics 14: 155-173.

Traugott, E.C. 1986. From Polysemy to Internal Semantic Reconstruction. Papers from the 12th Annual Meeting of the Berkeley Linguistic Society: 539-550.

Tsohatzidis, S.L. 1990. Meanings and Prototypes. Studies on Linguistic Categorization. Londen: Routledge.

Wierzbicka, A. 1990. "Prototypes save": On the Uses and Abuses of the Notion "prototype" in Linguistics and Related Fields. Tsohatzidis, S.L. (Red.). 1990: 347-368.

Zgusta, L. 1971. Manual of Lexicography. Den Haag: Mouton.

Zgusta, L. en D.M.T.Cr. Farina. 1988. Lexicography Today: An Annotated Bibliography of the Theory of Lexicography. Tübingen: Max Niemeyer. 